Article

\title{
Optimization of 1D/3D Electro-Thermal Model for Liquid-Cooled Lithium-Ion Capacitor Module in High Power Applications
}

\author{
Danial Karimi ${ }^{1,2}, * \mathbb{C}$, Hamidreza Behi ${ }^{1,2}\left(\mathbb{D}\right.$, Mohsen Akbarzadeh ${ }^{1,2}$, Sahar Khaleghi ${ }^{1} \mathbb{(}$, Joeri Van Mierlo ${ }^{1,2} \mathbb{D}$ \\ and Maitane Berecibar ${ }^{1}$ \\ 1 Research Group MOBI-Mobility, Logistics and Automotive Technology Research Centre, \\ Vrije Universiteit Brussel, Pleinlaan 2, 1050 Brussels, Belgium; Hamidreza.Behi@VUB.be (H.B.); \\ mohsen.akbarzadeh.sokkeh@vub.be (M.A.); sahar.khaleghi@vub.be (S.K.); joeri.van.mierlo@vub.be (J.V.M.); \\ Maitane.Berecibar@vub.be (M.B.) \\ 2 Flanders Make, 3001 Heverlee, Belgium \\ * Correspondence: Danial.Karimi@VUB.be; Tel.: +32-(499)-875-895
}

Citation: Karimi, D.; Behi, H.; Akbarzadeh, M.; Khaleghi, S.; Van Mierlo, J.; Berecibar, M. Optimization of 1D/3D Electro-Thermal Model for Liquid-Cooled Lithium-Ion Capacitor Module in High Power Applications. Electricity 2021, 2, 503-523. https:/ / doi.org/10.3390/electricity2040030

Academic Editor: Andreas Sumper

Received: 28 September 2021

Accepted: 29 October 2021

Published: 4 November 2021

Publisher's Note: MDPI stays neutral with regard to jurisdictional claims in published maps and institutional affiliations.

Copyright: (c) 2021 by the authors. Licensee MDPI, Basel, Switzerland. This article is an open access article distributed under the terms and conditions of the Creative Commons Attribution (CC BY) license (https:// creativecommons.org/licenses/by/ $4.0 /)$.

\begin{abstract}
Lithium-ion capacitor technology (LiC) is well known for its higher power density compared to electric double-layer capacitors (EDLCs) and higher energy density compared to lithium-ion batteries (LiBs). However, the $\mathrm{LiC}$ technology is affected by a high heat generation problem in high-power applications when it is continuously being charged/discharged with high current rates. Such a problem is associated with safety and reliability issues that affect the lifetime of the cell. Therefore, for high-power applications, a robust thermal management system (TMS) is essential to control the temperature evolution of LiCs to ensure safe operation. In this regard, developing accurate electrical and thermal models is vital to design a proper TMS. This work presents a detailed 1D/3D electro-thermal model at module level employing MATLAB/SIMULINK ${ }^{\circledR}$ coupled to the COMSOL Multiphysics ${ }^{\circledR}$ software package. The effect of the inlet coolant flow rate, inlet coolant temperature, inlet and outlet positions, and the number of arcs are examined under the cycling profile of a continuous 150 A current rate without a rest period for $1400 \mathrm{~s}$. The results prove that the optimal scenario for the LCTMS would be the inlet coolant flow rate of $500 \mathrm{~mL} / \mathrm{min}$, the inlet temperature of $30{ }^{\circ} \mathrm{C}$, three inlets, three outlets, and three arcs in the coolant path. This scenario decreases the module's maximum temperature $\left(\mathrm{T}_{\max }\right)$ and temperature difference by $11.5 \%$ and $79.1 \%$, respectively. Moreover, the electro-thermal model shows $\pm 5 \%$ and $\pm 4 \%$ errors for the electrical and thermal models, respectively.
\end{abstract}

Keywords: electro-thermal model; thermal management; optimization; liquid-cooled system; electric vehicles

\section{Introduction}

Electric vehicles (EVs) are becoming popular due to their zero emissions by employing electrical energy storage systems (ESSs) for traction [1]. The most-used ESSs are electric double-layer capacitors (EDLC) and lithium-ion batteries (LiBs) [2]. EDLCs show longer lifetime and higher power ratios, while they suffer from low energy density [3]. Although LiBs are exceptional solutions for high energy densities, low power density is their major drawback [4]. In this respect, lithium-ion capacitors (LiCs) have emerged that are hybrid ESSs [5]. The main benefits of LiCs are higher power compared to LiBs and higher energy compared to EDLCs, which make LiCs very reliable in high-power applications [6]. Nevertheless, excessive heat generation in high-power applications can reduce their performance and lifetime [7]. Thus, a robust cooling system should be designed to control the $\mathrm{LiC}^{\prime} \mathrm{s}$ temperature [8].

Before designing a thermal management system (TMS), the development of accurate electrical and thermal models is vital for further optimization of the developed system 
to guarantee the robustness of the proposed system [9]. In this context, following the development of a 1D electro-thermal model, a 3D thermal model should be developed [10]. A 3D thermal model is a computational fluid dynamics (CFD) model aiming for system optimization [11]. A 1D electrical model is responsible for extracting the electrical parameters, such as internal resistance, capacitance, and open-circuit voltage (OCV) [12], which will be used to extract the heat loss of the cell through the 1D thermal model [13]. The 3D thermal model will then employ the extracted power loss to predict the LiC's thermal behavior [14]. The 1D model in this work was developed in the MATLAB/SIMULINK ${ }^{\circledR}$ environment, and the 3D model was built in the COMSOL Multiphysics ${ }^{\circledR}$ software package.

Generally, active and passive cooling systems are the main methods to control the ESSs [15,16]. Passive systems include heat sinks [17], heat pipes [18], and phase change materials (PCM) [19]. Heat sinks are metal plates to enhance the heat flow away from a heat source [20]. Heat pipes are highly thermally conductive substances that remove the generated heat from heat sources; they have some drawbacks, such as complex design [21], low performance in high-power applications [22], and gravity dependency [23]. PCMs are materials that absorb and reject heat generation (thermal energy) when they are melted and frozen [24]. During the thermal cycling process, PCMs change their phase from solid to liquid. The major problem of PCMs is their very low thermal conductivity, which limits their applications [25]. Therefore, other highly conductive materials, such as heat pipes [26], graphite [27], nanomaterials [28], nanofluids [29], copper foams [30], or aluminum foams [31], should be added to PCMs to cope with this drawback.

On the other hand, active cooling systems comprise air and liquid cooling methods $[32,33]$. Air-cooled TMSs are reasonable solutions at low ambient temperatures when the inlet and outlet positions are well-structured and the inlet flow velocity is set accordingly [34]. The heat transfer rate of liquid-cooled TMSs is higher than air, making them a perfect candidate in high-power applications. Karimi et al. [34] developed an air cooling system for a LiC $2300 \mathrm{~F}$ cell and decreased the maximum temperature of the cell by $14 \%$. Akbarzadeh et al. [35] compared an air cooling system with a liquid cooling system for a module of $\mathrm{LiB}$, in which they proved that the temperature uniformity of the liquid-cooled system was better than that of the air cooling system. Gungor et al. [36] proposed a liquid cooling design for EVs. They proved that a canopy-to-canopy architecture has high thermal performance to maintain the battery cell in the desired range. Tang et al. [37] designed and optimized a lightweight cooling system for four prismatic batteries. Their proposed design had $1.88 \%$ and $2.36 \%$ weight ratios. Tang et al. [38] designed an automatic calibrated model for TMS based on the SVR model with RBF kernel. Cao et al. [39] upgraded a liquid cooling TMS using composite PCMs. They showed that the battery's maximum temperature and temperature uniformity were below $46^{\circ} \mathrm{C}$ and $4{ }^{\circ} \mathrm{C}$, respectively. Rui et al. [40] established a 3D thermal runaway propagation (TRP) model with liquid-cooled structures and showed that the criticality boundary could guide the safety design aspects for the TMS.

To the best of the authors' knowledge, no work in the literature has proposed a liquid-cooled system for a module of $12 \mathrm{LiC}$ cells cycled under a $150 \mathrm{~A}$ harsh current rate. This paper continues the work published in [41], in which two cold plates cooled a LiC cell. Moreover, in this article, a detailed 1D/3D electro-thermal model is developed at module level employing MATLAB/SIMULINK ${ }^{\circledR}$ coupled to the COMSOL Multiphysics ${ }^{\circledR}$ software package, used to optimize the proposed cooling system. The design optimization parameters are the effect of the inlet coolant flow rate, inlet coolant temperature, inlet and outlet positions, and the number of arcs. Finally, a conclusion is made at the end of this work that combines all the optimized design parameters to yield the most optimized liquidcooled TMS (LCTMS) regarding the proposed cooling system's architecture and geometry.

\section{Numerical Solution}

The present work introduces a 1D electro-thermal model coupled to a 3D thermal model to validate and optimize a forced liquid-cooled TMS (LCTMS). The proposed LCTMS is responsible for cooling down the $\mathrm{LiC} 2300 \mathrm{~F}$ in high-power applications. In this regard, a 
high current rate of $150 \mathrm{~A}$ is applied to the module continuously without a rest period for $1400 \mathrm{~s}$. The characteristics of the target cell used in the module are listed in Table 1.

Table 1. LiC 2300 F specifications.

\begin{tabular}{ccc}
\hline Parameters & Value & Unit \\
\hline Nominal capacity & 1 & $\mathrm{Ah}$ \\
Voltage & $2.2-3.8$ & $\mathrm{~V}$ \\
DC-IR @25 ${ }^{\circ} \mathrm{C}$ & 0.7 & $\mathrm{~m} \Omega$ \\
Energy density & 14 & $\mathrm{Wh} / \mathrm{L}$ \\
Power density & 14.7 & $\mathrm{~kW} / \mathrm{L}$ \\
Heat generation & 76,477 & $\mathrm{~W} / \mathrm{m}^{3}$ \\
\hline
\end{tabular}

In this experimental and numerical study, the $1 \mathrm{D} / 3 \mathrm{D}$ numerical simulation analysis has been carried out using MATLAB SIMULINK ${ }^{\circledR}$ and COMSOL Multiphysics ${ }^{\circledR}$. In the coupled 1D/3D model, the 1D electrical model identifies the electrical parameters used while the 1D thermal model extracts the thermal parameters. The heat dissipation of the cell is extracted using the 1D model. Then, the system's heat loss is imported into the 3D thermal model to develop the LCTMS CFD simulation and optimization. The 1D electrical and thermal models are developed in the MATLAB SIMULINK ${ }^{\circledR}$ environments, while the 3D thermal model is developed in COMSOL Multiphysics ${ }^{\circledR}$. This coupled 1D/3D model development reduces the simulation time. Figure 1 exhibits how the 1D electrical and thermal models are linked to the 3D CFD model.

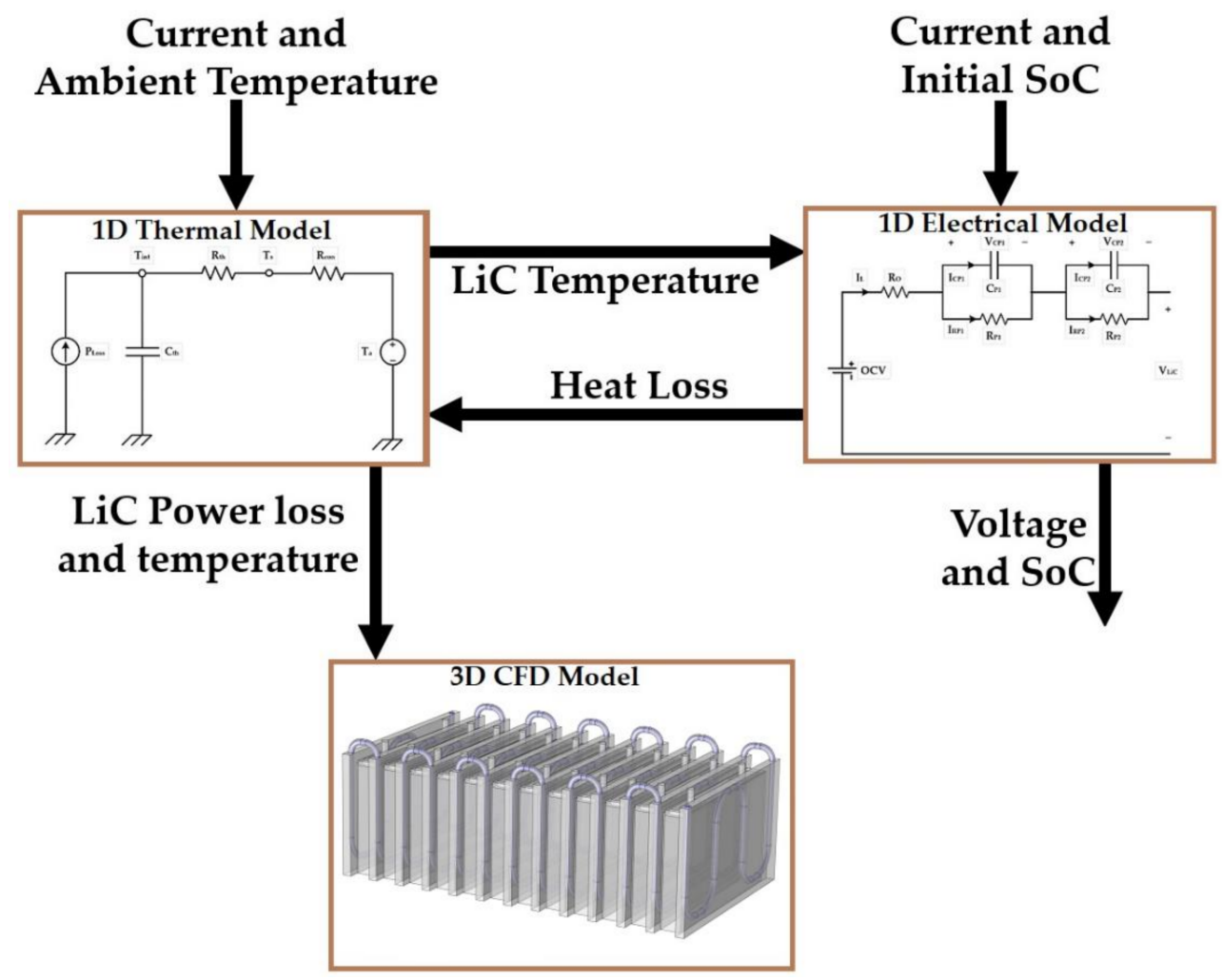

Figure 1. The 1D electro-thermal model coupled to the 3D CFD model.

\subsection{LiC 2300 F Electrical Model}

The 1D electrical model is developed to identify the internal electrical parameters (open-circuit voltage $(\mathrm{OCV}[\mathrm{V}])$, ohmic resistance $\left(R_{0}[\Omega]\right)$, polarization resistance $\left(R_{P}\right.$ $[\Omega])$, and polarization capacitance $\left.\left(C_{P}[\mathrm{~F}]\right)\right)$ of $2300 \mathrm{~F} \mathrm{LiC}$ under high current rates $(I$ [A]) within a wide range of temperatures $\left(\mathrm{T}\left[{ }^{\circ} \mathrm{C}\right]\right)$. The electrical model is a second-order equivalent circuit model (ECM) that includes two RC circuits. RC denotes the resistance 
and capacitance of the $\mathrm{LiC}$ cell. Based on the governing equations and the chosen secondorder ECM, the electrical parameters of the LiC are identified. The terminal voltage $\left(V_{t}[\mathrm{~V}]\right)$ of the $2300 \mathrm{~F} \mathrm{LiC}$ is expressed as [12]:

$$
\begin{gathered}
V_{t}=O C V(S o C, T)-I_{L} R_{0}\left(S o C, T, I_{L}\right)-V_{C P 1}\left(S o C, T, I_{L}\right)-V_{C P 2}\left(S o C, T, I_{L}\right) \\
\frac{d V_{C P i}}{d t}=-\frac{1}{R_{P i} C_{P i}} V_{C P i}+\frac{1}{C_{P i}} I_{L} \\
\tau_{i}=R_{P i} C_{P i}
\end{gathered}
$$

The extracted parameters for the second-order ECM at $25^{\circ} \mathrm{C}$ under a high current rate of $150 \mathrm{~A}$ for $100 \%$ SoC values are listed in Table 2. As is evident, all these parameters depend highly on temperature. Figure 2 shows the current and voltage applied to the cell. It is revealed that the heat loss of the cell increases sharply at the beginning of the cycling, following a slight decrease that comes from the temperature change of the cell during the charge and discharge processes.

Table 2. Extracted parameters of the electrical model at $25^{\circ} \mathrm{C}, 150$ A current rate, and $100 \%$ SoC.

\begin{tabular}{ccc}
\hline Extracted Parameters & Value & Symbols \\
\hline Open-circuit voltage & 3.8 & OCV [V] \\
Ohmic resistance & 0.0011 & $R_{0}[\Omega]$ \\
Polarization resistance & 0.00013 & $R_{P}[\Omega]$ \\
Time constant & 0.1336 & $\tau[\mathrm{s}]$ \\
\hline
\end{tabular}

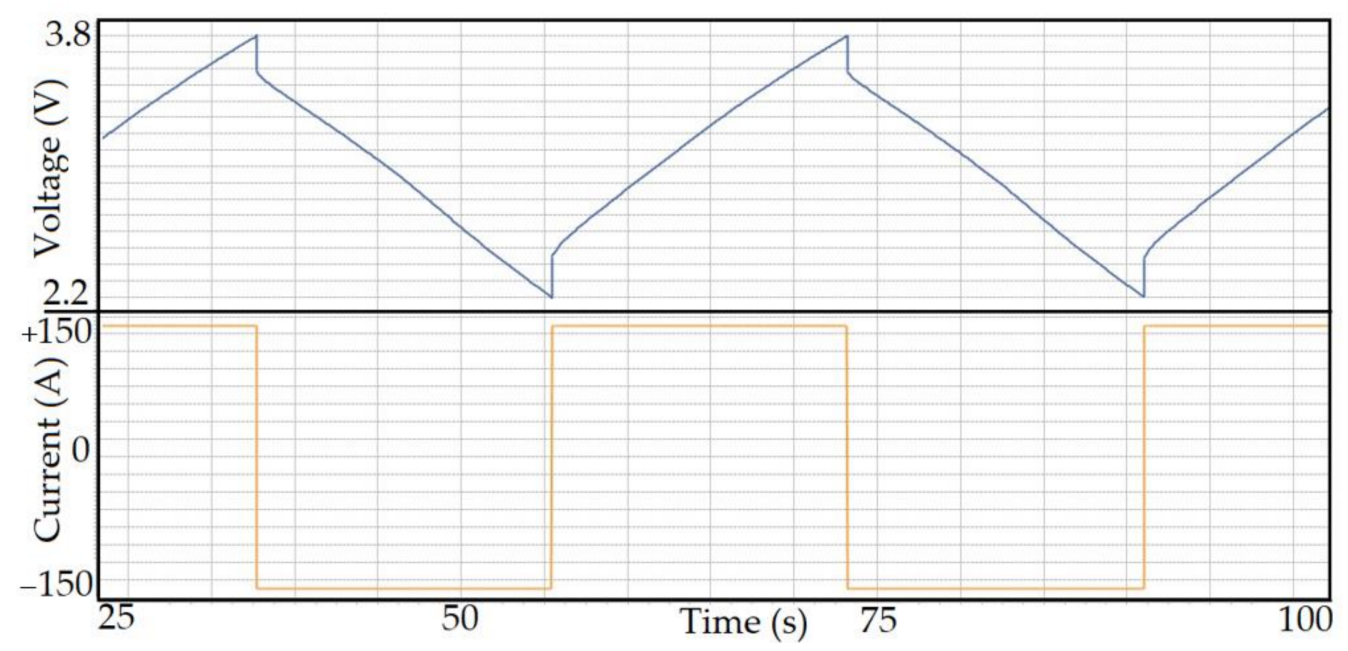

Figure 2. A segment of the applied current and voltage (up), and power loss of the LiC under fast charge/discharge with continuous $150 \mathrm{~A}$ current rate during 1400 s experimental test (down).

\subsection{LiC 2300 F Thermal Model}

The thermal model of the $\mathrm{LiC}$ is divided into one-dimensional and three-dimensional models. The first one is responsible for extracting the heat loss of the cell. In contrast, the second one uses the extracted loss to simulate the $\mathrm{LiC}$ under various operating conditions for validation purposes and optimization analysis.

\subsubsection{D Thermal Model}

In this work, the surface temperature of the $\mathrm{LiC}$ is modeled to estimate the thermal parameters precisely. The essential parameters of the model are the heat loss of the $\mathrm{LiC}$, the initial temperature of the cell, and ambient temperature. The heat loss of the cell is divided into reversible and irreversible heat that stems from the entropy changes and internal resistance of the cell, respectively. The entropy change (reversible heat) can be positive or 
negative, but the internal resistance (irreversible heat) is always positive. In this regard, the power loss of the cell is expressed as [13]:

$$
P_{\text {loss }}=I_{L}^{2} R_{0}\left(S o C, T, I_{L}\right)+I_{R P 1}^{2} R_{P 1}\left(S o C, T, I_{L}\right)+I_{R P 2}^{2} R_{P 2}\left(S o C, T, I_{L}\right)-I_{L} T_{\text {cell }} \frac{\partial O C V\left(T_{\text {cell }}, S o C\right)}{\partial T_{\text {cell }}}
$$

where $P_{\text {loss }}[\mathrm{W}]$ denotes the heat loss of the LiC cell and $T_{\text {cell }}\left[{ }^{\circ} \mathrm{C}\right]$ is the temperature of the LiC. Figure 3 demonstrates the heat loss under fast charge/discharge with a continuous 150 A current rate during the $1400 \mathrm{~s}$ experimental test.

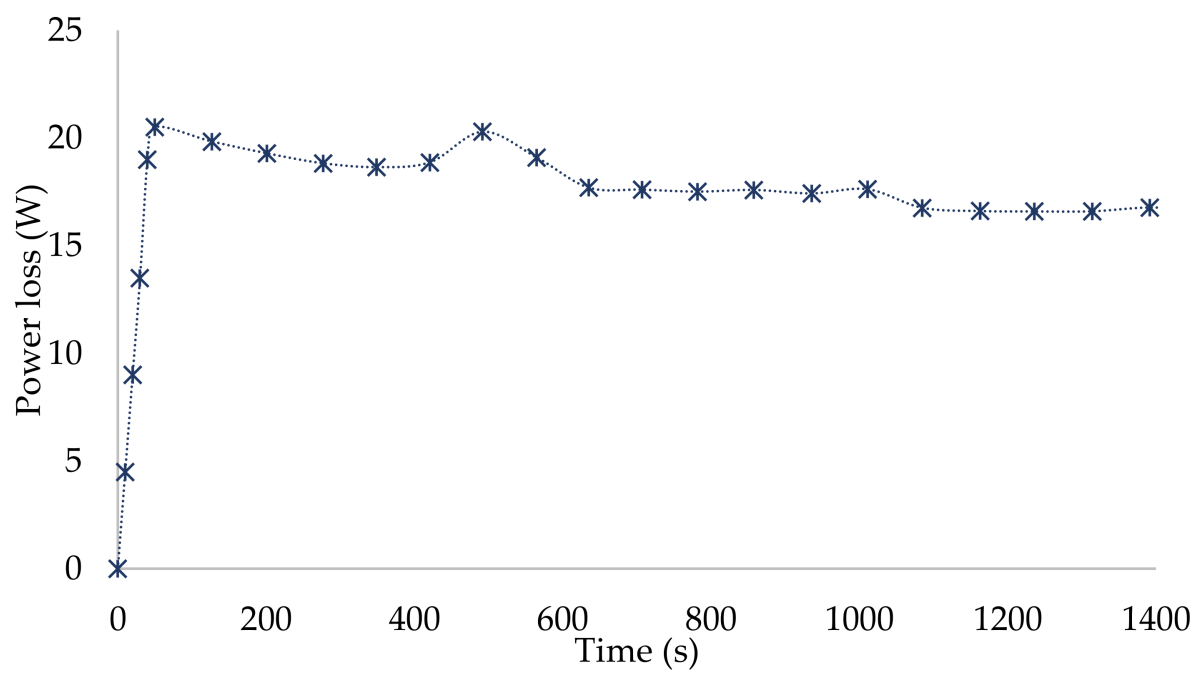

Figure 3. The power loss of the $\mathrm{LiC}$ single cell under fast charge/discharge with continuous $150 \mathrm{~A}$ current rate during $1400 \mathrm{~s}$ experimental test.

The generated heat of the $\mathrm{LiC}$ regarding its dimensions for a $150 \mathrm{~A}$ fast charging and fast discharging profile is listed in Table 3, which demonstrates that the generated heat of the $\mathrm{LiC}$ is 3.5 times larger than the normal heat generation condition of LiBs [42].

Table 3. The generated heat of the $\mathrm{LiC}$ regarding its dimensions for a $150 \mathrm{~A}$ current profile.

\begin{tabular}{cc}
\hline LiC Dimensions $(\mathbf{m m})$ & Heat Generation $\left(\mathrm{W} / \mathbf{m}^{\mathbf{3}}\right)$ \\
\hline $150 \times 91.5 \times 15.5$ & 76,477 \\
\hline
\end{tabular}

\subsubsection{D Thermal Model}

Heat generation of the LiC during its operation occurs mainly because of the ion migration process, which incorporates the electrochemical reaction, the side reaction, and the Joule losses [43]. The losses related to side reactions can be neglected due to the $\mathrm{LiC}^{\prime} \mathrm{s}$ operation at safe temperatures [44]. As mentioned in the 1D thermal modeling subsection, the reversible $\left(\dot{q}_{\text {rev }}\right)$ and irreversible $\left(\dot{q}_{i r r}\right)$ heat sources are the main contributors to the heat generation of the $\mathrm{LiC}\left(\dot{q}_{\text {gen }}\right)$, which come from entropy change and internal resistance, respectively [45]. In addition, cell and tab domains are considered in the heat generation modeling of the $\mathrm{LiC}$ due to the non-uniform temperature distribution. The heat generation of the cell domain can be expressed as:

$$
\dot{q}_{g e n}=\dot{q}_{i r r}+\dot{q}_{r e v}=I(U-V)-I T \frac{\partial U}{\partial T}
$$

For the tab domain, the heat generation is expressed as:

$$
\dot{q}_{g e n}=\frac{R I^{2}}{V_{t a b}}
$$


Based on the density $(\rho)$ and specific heat $\left(C_{p}\right)$ in the 3D thermal model, the energy conservation is expressed as:

$$
\rho C_{p} \Delta V \frac{\partial T}{\partial t}=\Delta(U A)_{x} \frac{\partial T}{\partial x}+\Delta(U A)_{y} \frac{\partial T}{\partial y}+\Delta(U A)_{z} \frac{\partial T}{\partial z}+\Delta \dot{q}_{g e n}
$$

For the liquid cooling system model, the Reynolds number determines the turbulent or laminar flow, which directly depends on the hydraulic diameter $\left(d_{c}\right)$, coolant density $\left(\rho_{c}\right)$, and velocity $\left(v_{c}\right)$ :

$$
\begin{gathered}
R e=\frac{\rho_{c} v_{c} d_{c}}{u_{c}} \\
d_{c}=\frac{4 A_{c}}{P_{c}} \frac{4 \pi r_{c}^{2}}{2 \pi r_{c}}
\end{gathered}
$$

where $A_{c}, P_{c}$, and $r_{c}$ represent the channel cross-sectional area, perimeter, and radius. In the present work, the length of the channel is much larger than its cross-sectional area. Therefore, the flow should be considered as a fully developed flow. The Gnielinski correlation is employed to obtain the convective heat transfer coefficient [46]:

$$
N u_{\text {cool }}=\frac{\left(\frac{f_{\text {cool }}}{8}\right)\left(R e_{\text {cool }}-1000\right) P r_{\text {cool }}}{1+12.7\left(\frac{f_{\text {cool }}}{8}\right)^{1 / 2}\left(\operatorname{Pr}_{\text {cool }}^{0.66}-1\right)}, \quad 2300<R e_{\text {cool }}<5 \times 10^{6}
$$

The Darcy friction factor $\left(f_{\text {cool }}\right)$ for the coolant is achieved by having the channel's aspect ratio $(\gamma)[47]$ :

$$
f_{\text {cool }}=(1.0875-0.1125 \gamma) \cdot f_{\text {cool }, 0}
$$

Considering the channel length $(L)$ and diameter $(D)$, the pressure drop of the LCTMS is expressed as:

$$
\Delta P=\sum_{i=1}^{n} f_{\text {cool }} \rho_{\text {cool }}\left(\frac{L}{D}\right)_{\text {eqv }} \frac{v_{\text {cool }}^{2}}{2}
$$

\begin{tabular}{|c|c|c|c|}
\hline Domain & Condition & Value & Unit \\
\hline Module domain & $\mathrm{T}_{\text {init }}$ & 23 & ${ }^{\circ} \mathrm{C}$ \\
\hline Cold plates & $\mathrm{T}_{\text {init }}$ & 23 & ${ }^{\circ} \mathrm{C}$ \\
\hline Type of coolant & water & - & - \\
\hline Coolant pressure & Reference level & 1 & atm \\
\hline Coolant domain & $\mathrm{T}_{\text {inlet }}$ & 23 & ${ }^{\circ} \mathrm{C}$ \\
\hline Coolant flow rate & $\mathrm{Q}_{\text {inlet }}$ & 100 & $\mathrm{~mL} / \mathrm{min}$ \\
\hline Coolant flow rate & Turbulent & Incompressible & - \\
\hline Coolant tube & wall & No-slip & - \\
\hline Coolant outlet & $P_{\text {Outlet }}$ & To ambient & - \\
\hline Coolant outlet & $Q_{\text {outlet }}$ & Suppressed outflow & - \\
\hline
\end{tabular}

The system's parameters, initial conditions, and boundaries are set in the 3D CFD model to verify the numerical simulations against the experiments. Table 4 shows the initial conditions and boundaries of the LCTMS.

Table 4. Initial conditions and boundaries of the 3D thermal system.

The next step would be mesh generation and setting the step time and solver directly related to the system's complexity and computational time. After analyzing different grid densities, the mesh element number of 6,426,351 was utilized with a $1 \mathrm{~s}$ time step.

\section{Experimental Test Bench}

The facilities used in the experimental investigation are a module of $12 \mathrm{LiC}$ cells, 13 cold plates, a battery management system (BMS), a data logger, eight k-type thermocouples, a radiator, a pump, a power supply, a battery tester, and a computer. 


\subsection{Battery Management System (BMS)}

The most vital element of the module used to monitor and control the voltage of all the cells, balance the state of charge (SoC), and monitor the temperature of each cell is the battery management system (BMS). The BMS is necessary to protect the cells against over-charging/discharging, and they are connected in series. The importance of the BMS lies in overcoming the voltage and SoC imbalance among the cells. In this work, a passive BMS is used to balance the LiC cells with low costs. The main functions of the utilized BMS are:

- Parameter measurement (voltage, current, resistance, and temperature);

- Safety and protection against over-charging/discharging, over-temperature, current limit;

- Communication through CAN-bus or RS-485 port.

In this work, the BMS is used to equalize the LiC voltages by using $10 \mathrm{ohmic}$ resistors called the switched shunt resistor. Figure 4 exhibits the block diagram of the experimental test bench for the LiC module while employing a BMS for balancing the cells and protecting the module. This can be done by monitoring the module's temperature, voltage, and current at each time step. The current of the module is measured by a low-side precision shunt ohmic resistor with $0.25 \%$ accuracy. Additionally, the voltage drop of the module is measured by the shunt ohmic resistor thanks to its four-wire Kelvin connection. The BMS is connected to the shunt ohmic resistor via a short shielded cable. The ADC (analog to digital converter) with high accuracy filters out the noise or the current spikes. The temperature profile of the module is monitored by the $\mathrm{K}$-type thermocouples and a data logger. Two small fans and a heat sink are added to protect the BMS from over-heating. The prototype of the used BMS and the wiring/connections is depicted in Figure 5.

\subsection{Test Bench Setup}

A forced LCTMS is used for cooling purposes in this work to cool down the temperature rise of the $\mathrm{LiC} 2300 \mathrm{~F}$ module in harsh operating conditions. The module is composed of 12 prismatic LiC cells connected in series. The LCTMS is composed of 13 cold plates, meaning that every two cold plates are attached to the left and right sides of the larger surface of the $\mathrm{LiC}$ cell. In the main case study, the inlet flow rate is set at $100 \mathrm{~mL} / \mathrm{min}$ with an initial temperature of $23^{\circ} \mathrm{C}$. The pump is responsible for drawing the coolant from the tank storage to the cold plates. The coolant flow path is from the first cold plate to the last cold plate. Therefore, it is expected that the first cells experience a lower temperature, while the middle cells to the last should be hotter. The last cell (cell \#12) is expected to be colder than the adjacent cells due to the heat flux, since one side of this cell is exposed to the ambient temperature. Figure 6 demonstrates the facilities used in this work.

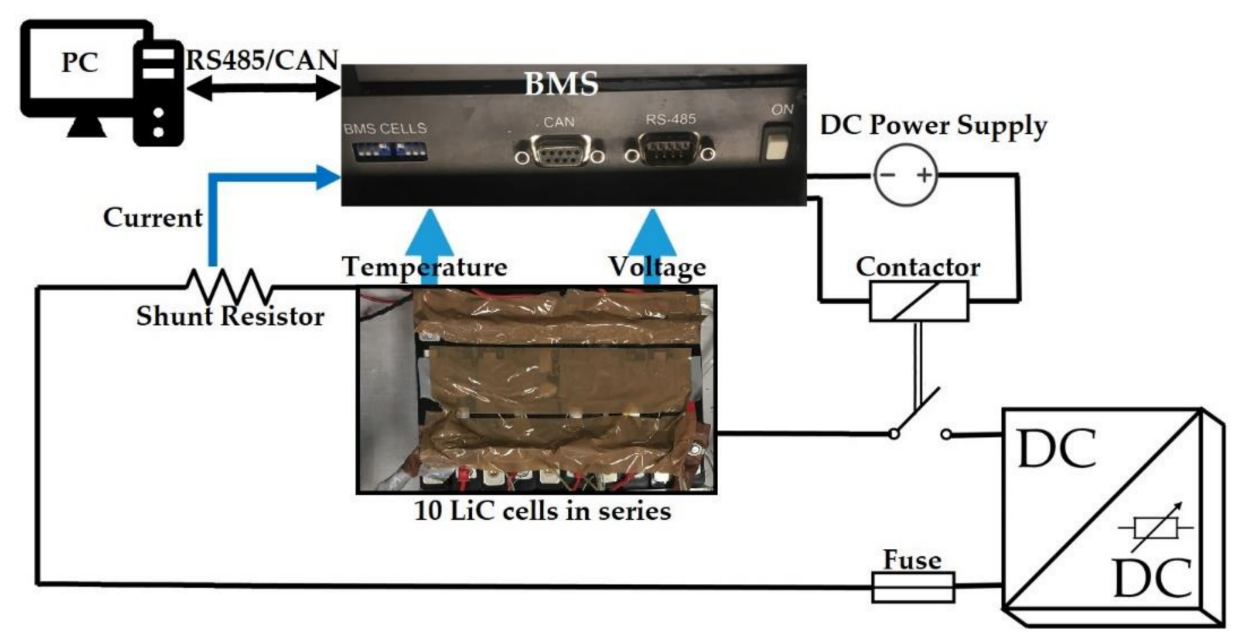

Figure 4. The block diagram of the experimental test bench for the LiC module. 


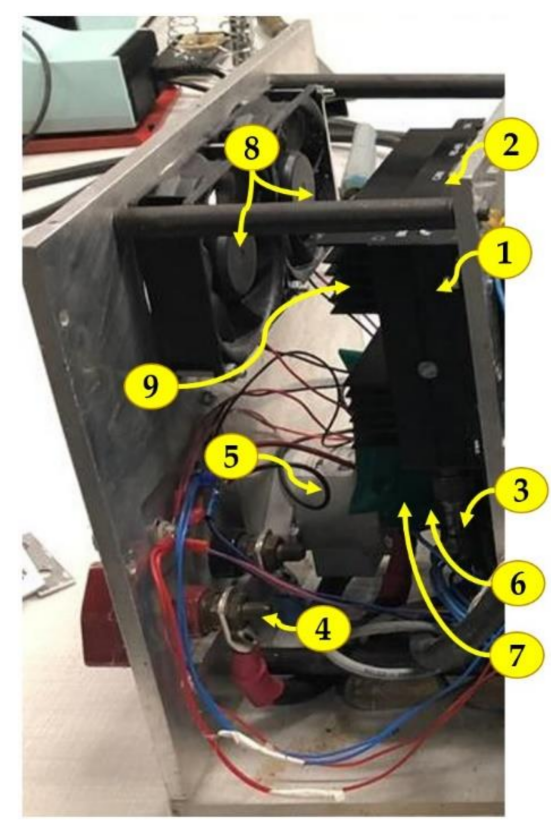

\section{1) BMS}

2) RS-485 to USB

3) Current \& Temperature sensors

4) Shunt resistor

5) Contactor

6) Voltage sensors (below the BMS)

7) Protection control signal

8) Fan (for BMS cooling)

9) Heat sink (stuck to the BMS)

Figure 5. The prototype of the used BMS and the wiring/connections.

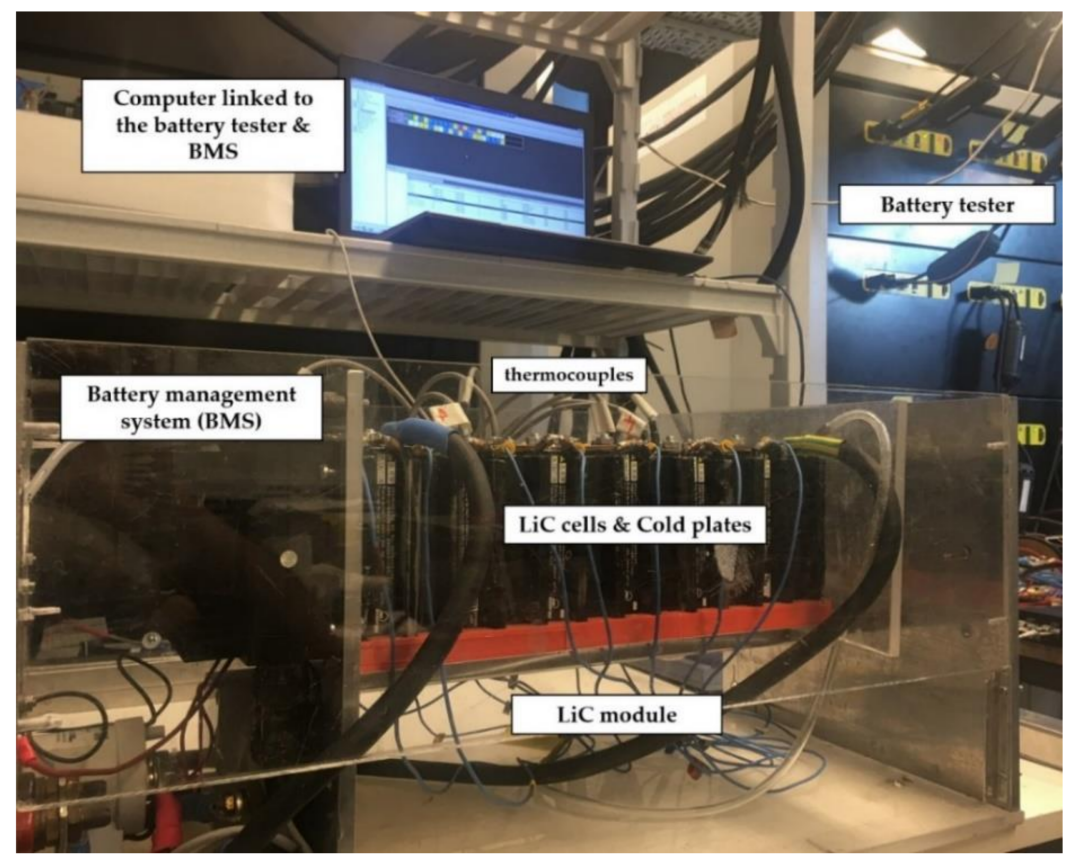

Figure 6. The forced LCTMS experimental test bench for the LiC module.

As is depicted in Figure 7, the computer is connected to the BMS through a CANbus or RS-485 port. On the other side, the computer is connected to the data logger to monitor the module's temperature evolution during the experiments. The battery tester is responsible for applying the current and voltage to the module for cycling the cells. Two fans and a heat sink are embedded in the BMS part to cool it down in order to avoid failure of the BMS. The radiator cools down the coolant coming from the outlet of the cold plates. The coolant outlet temperature is directly proportional to the heat generation rate, but the inlet temperature of the coolant is almost $23^{\circ} \mathrm{C}$, thanks to the highly efficient radiator. The pump flows the coolant from the storage tank to the inlet of the LCTMS. In addition, $8 \mathrm{~K}$-type thermocouples monitor the temperature at each time step, for which, in this work, the time step of the data logger and thermocouples is set to $1 \mathrm{~s}$. This means that the thermocouples and the data logger save the temperature data every $1 \mathrm{~s}$. The position of 
the thermocouples is shown in Figure 8. Based on the temperature of the cells, from colder to hotter cells, the number of the thermocouples was set to be more apparent from colder to hotter points in the graphical temperature evolution curves. The expected results would be colder temperatures for the $\mathrm{T} 1$ to $\mathrm{T} 4$ thermocouples and hotter temperatures for the $\mathrm{T} 5$ to T8 thermocouples. The experimental results are explained in the next section.

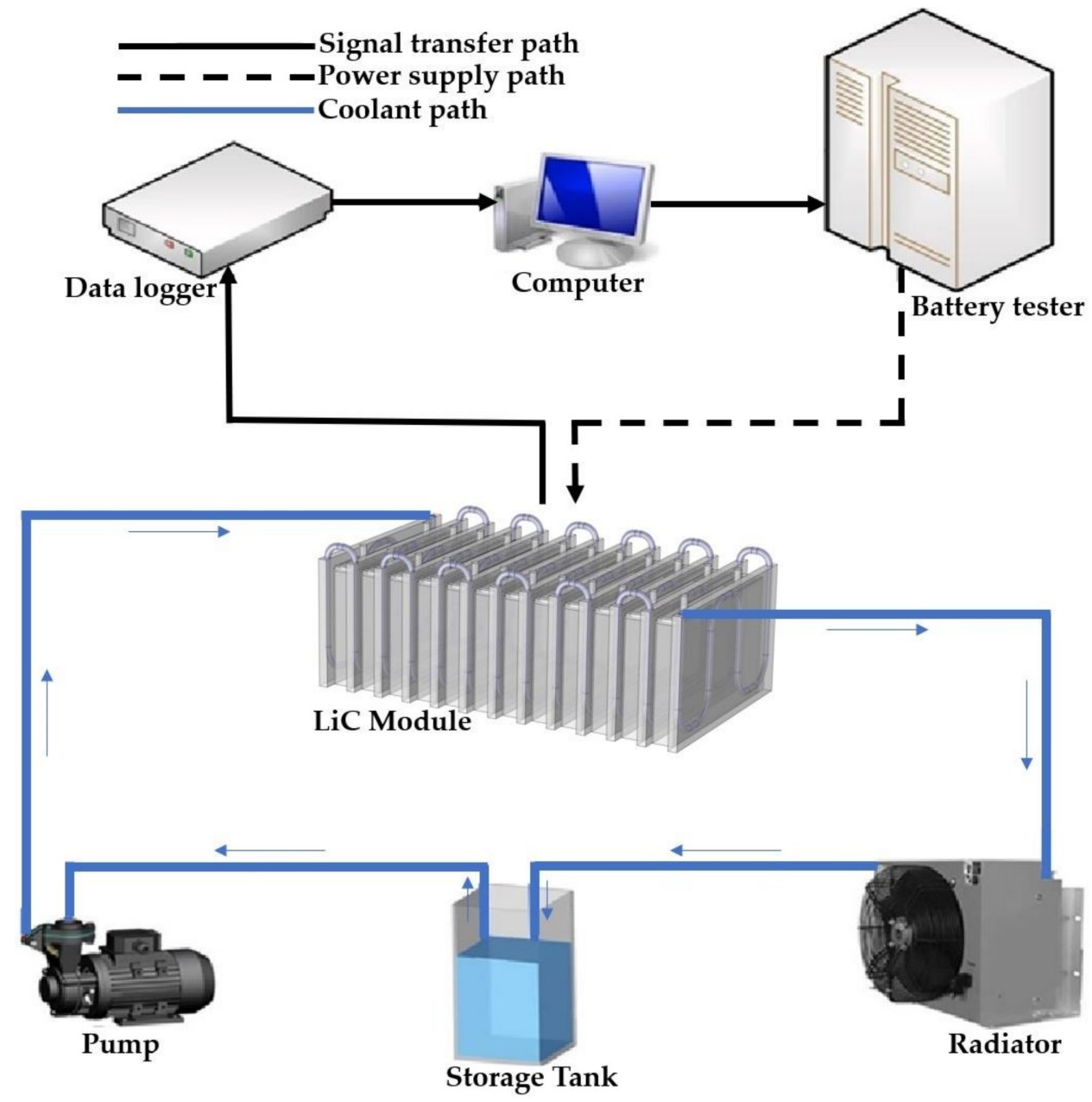

Figure 7. The schematic of the test bench for the proposed LCTMS.

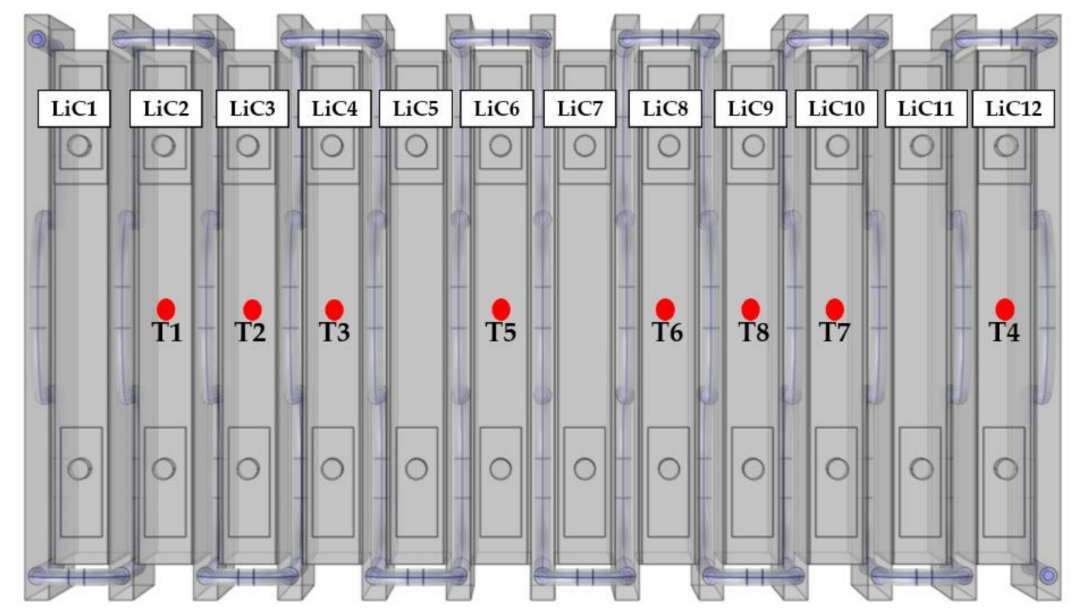

Figure 8. The position of $8 \mathrm{~K}$-type thermocouples regarding their temperature values; $\mathrm{T} 1$ is the lowest and $\mathrm{T} 8$ is the hottest (top view). 


\subsection{Experimental Results}

The experimental results have two parts: electrical results and thermal results. The electrical part explains the results of the extracted parameters for the electrical model. Figure 9 shows the open circuit voltage of the $\mathrm{LiC}$ versus $\mathrm{SoC}$ for the discharging of the cell at a 10 A current rate. Figure 10 demonstrates the validation of the electrical model regarding the extracted parameters within a heavy-duty driving profile with high current rates. The voltage simulation results are compared with the experiments in Figure 10a, which shows $\pm 5 \%$ and $\pm 3 \%$ for current rates higher than $100 \mathrm{~A}$ and lower than $100 \mathrm{~A}$, respectively, as is seen in Figure 10b.

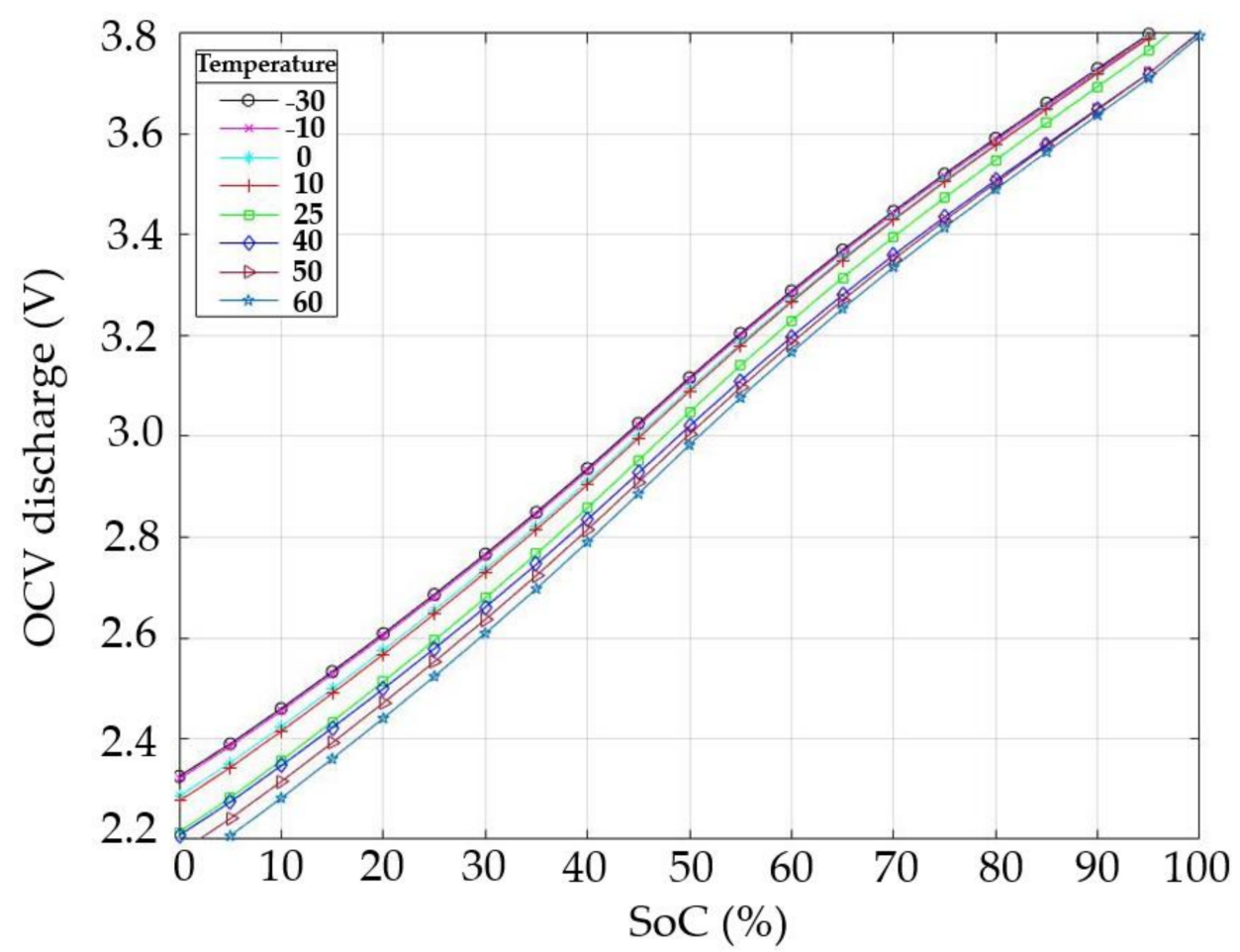

Figure 9. The OCV-SoC curve for discharging of the $\mathrm{LiC}$ cell at $10 \mathrm{~A}$ current.
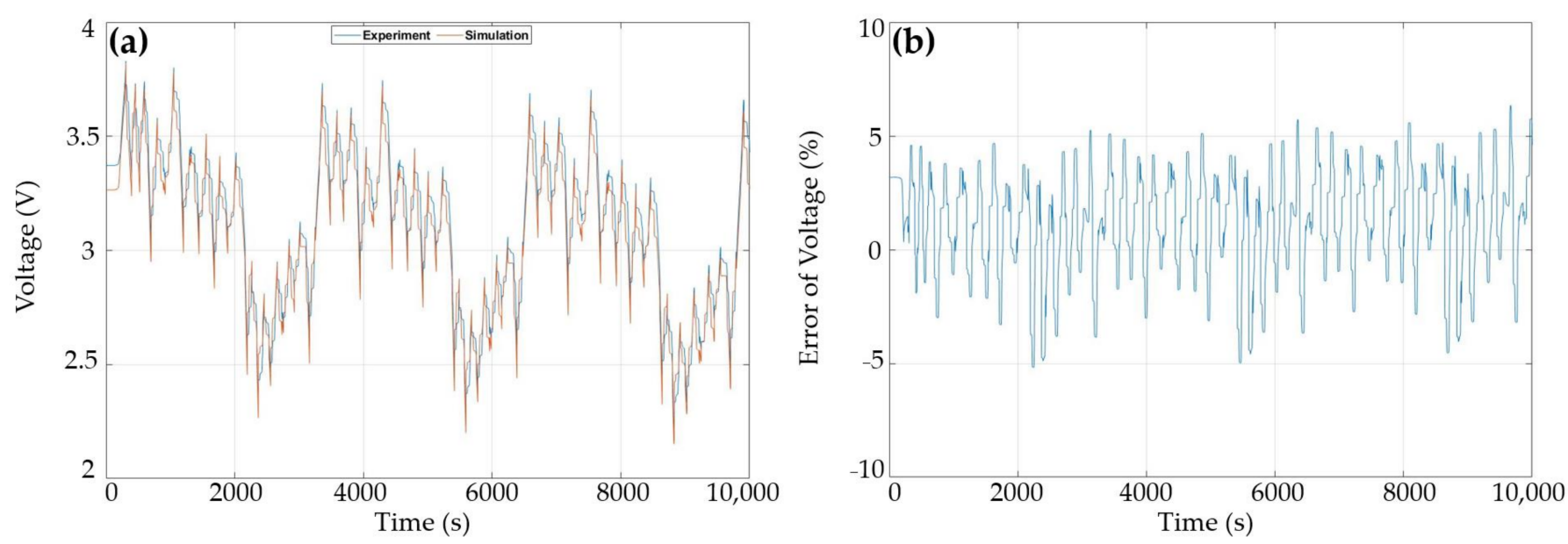

Figure 10. Verification of the electrical model: (a) the voltage simulation results against experiments, and (b) the voltage error percentage.

The experiments for thermal studies were conducted under the 150 A current profile for the LiC module when using LCTMS as the proposed cooling system. Before using the LCTMS, the thermal performance of the module without any cooling system under natural 
convection (NC) was evaluated. In this case, the maximum temperature of the module under $\mathrm{NC}$ is around $70^{\circ} \mathrm{C}$, which is much higher than the safe operating temperature of $40{ }^{\circ} \mathrm{C}$ announced by the manufacturer (JSR company). Therefore, an adequate cooling regime should be applied to the system to control its temperature. The temperature evolution of the module for all the thermocouples is depicted in Figure 11, in which the expected explained temperature rise for the cells within the module is proven. As is observed, the T1, T2, and T3 thermocouples are mounted on the top surface of the cell at the beginning of the module, where the coolant air is still cold. Therefore, their temperature rise is lower than that of the other cells. The T4 thermocouple relates to cell number 12, which is the last cell, and there are no cells after this cell. Therefore, T4 is exposed to the environment from one side, causing this cell to be colder than the other cells in the middle of the module. The T5, T6, T7, and T8 thermocouples relate to the cells in the middle, so from one side, their heat sources are generating heat, and from another side, the conduction effect is the dominant phenomenon between two adjacent cells. Thus, the middle cells to the last cell are much higher than the rest of the module (the first five cells).

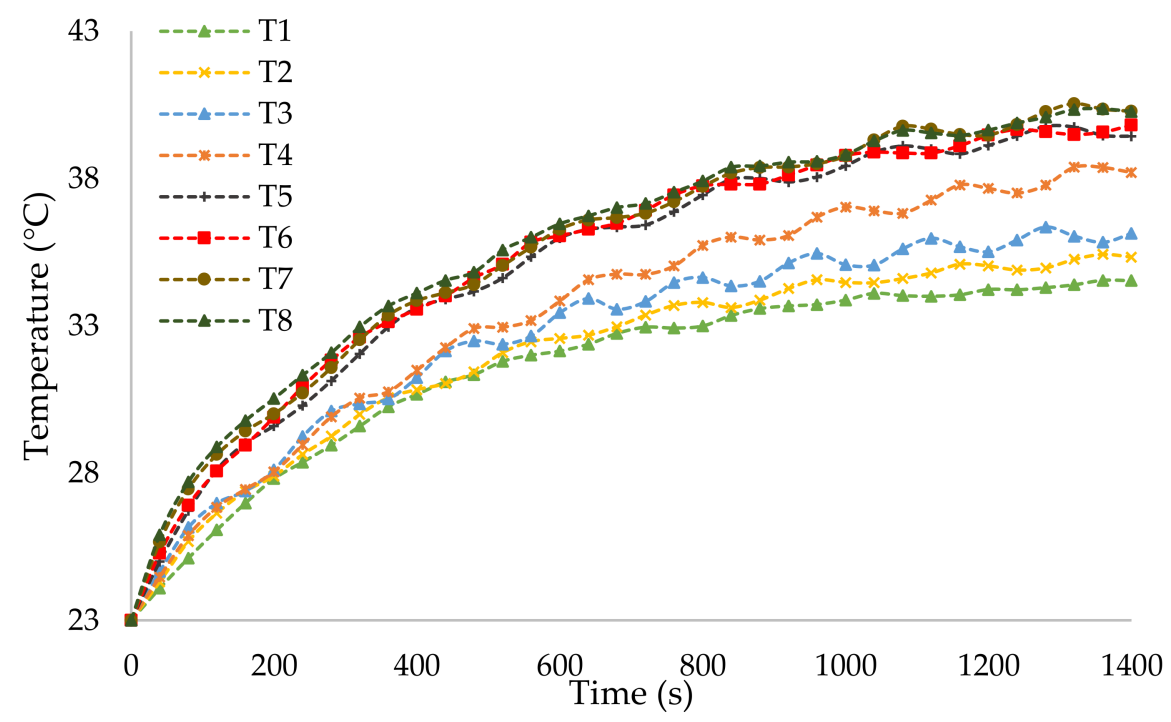

Figure 11. The experimental results: the temperature evolution of the module regarding the eight thermocouples embedded on top surfaces of the cells.

\section{Numerical Investigation and Optimization}

The experimental analysis is validated with numerical simulations in this section to prove the accuracy of the 1D/3D models. Later, the developed 3D model is optimized to obtain the best design for the proposed solution.

\subsection{Forced Liquid-Cooled Simulation Results}

The results of the 3D thermal model are presented in this section, thanks to the COMSOL Multiphysics software package. In the software, the heat transfer in solids module is employed to model the heat source and the general physics of the system, while the fluid flow module ( $\mathrm{k}-\varepsilon$ turbulent flow) is used to model the cooling system and the coolant. The initial conditions, boundary conditions, materials, parameters, and geometry of the system are set in the software, and the mesh is generated in the last step. The simulation results are shown in Figure 12 for the main case study regarding Table 4. Comparing the simulation and experimental results exhibits less than $3 \%$ error, which shows the precision of the developed 1D electro-thermal model's extracted parameters and the accuracy of the designed 3D thermal model. The graphical thermal results of the LCTMS for the LiC module are depicted in Figure 13. This provides a better insight into the temperature distribution over each module cell, resulting in better optimization of the 
system. As can be seen, the coldest cell is the first cell, and the hottest one is cell number 8 in the middle-end of the module.

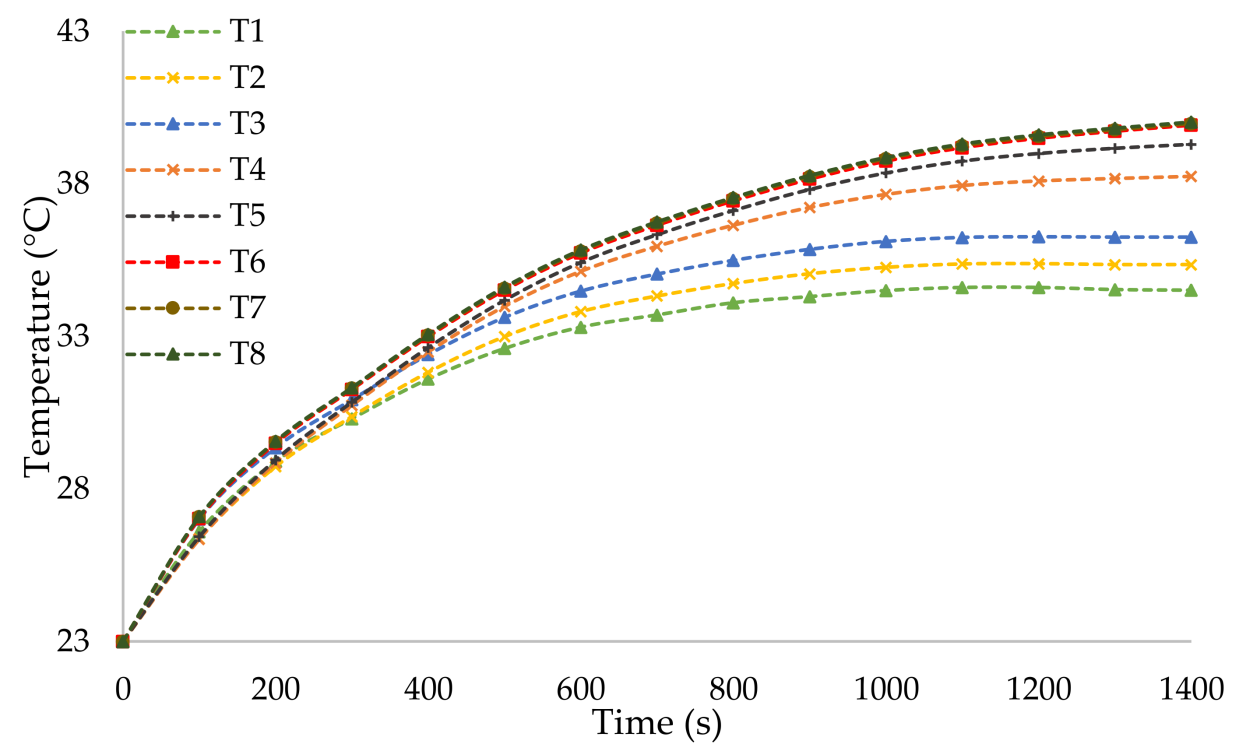

Figure 12. The simulation results: the temperature evolution of the module regarding the eight thermocouples embedded on top surfaces of the cells.

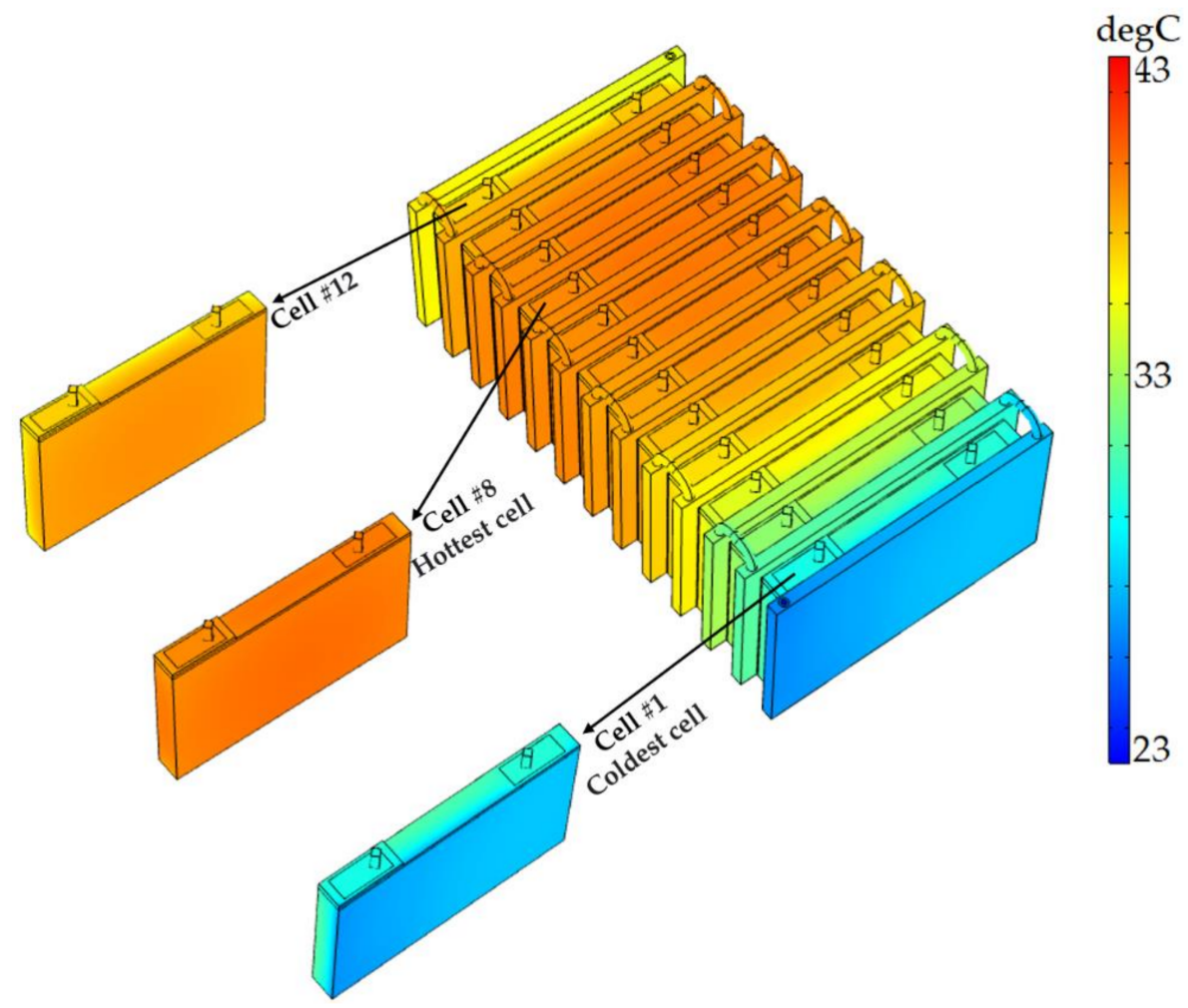

Figure 13. The temperature distribution of the module after $1400 \mathrm{~s}$.

Two performance indicators are evaluated in the numerical simulations:

- $\mathrm{T}_{\text {max }}$ : the maximum temperature on the LiC module's surface that is monitored by eight thermocouples.

- $\Delta \mathrm{T}_{\max }$ : the temperature difference between the maximum and minimum temperatures that are sensed by the thermocouples. 


\subsection{Impact of the Inlet Flow Rate}

The inlet flow rate of the coolant medium is a critical controlling factor for the LCTMS that directly affects the thermal performance and power consumption of the system. In order to study the impact of the inlet flow rate on the thermal performance of the LiC module, under the initial conditions and boundaries in Table 4, the inlet flow rate was set as $200 \mathrm{~mL} / \mathrm{min}, 300 \mathrm{~mL} / \mathrm{min}, 400 \mathrm{~mL} / \mathrm{min}, 500 \mathrm{~mL} / \mathrm{min}$, and $1000 \mathrm{~mL} / \mathrm{min}$, where the inlet and outlet positions and the tube diameter were kept constant. The thermal performance of the $\mathrm{LiC}$ module is depicted in Figure 14 for all six case studies, where the inlet flow rate of the main case study is $100 \mathrm{~mL} / \mathrm{min}$. The main reason for $\Delta \mathrm{T}_{\max }$ along the module is the inconsistency of the heat transfer rate of each LiC cell in the module, which is due to the tube structure, cell location, and other factors. Therefore, when the liquid enters the copper tube, the cells' temperature changes rapidly, widening the temperature gap between the coldest and hottest points monitored by the thermocouples.

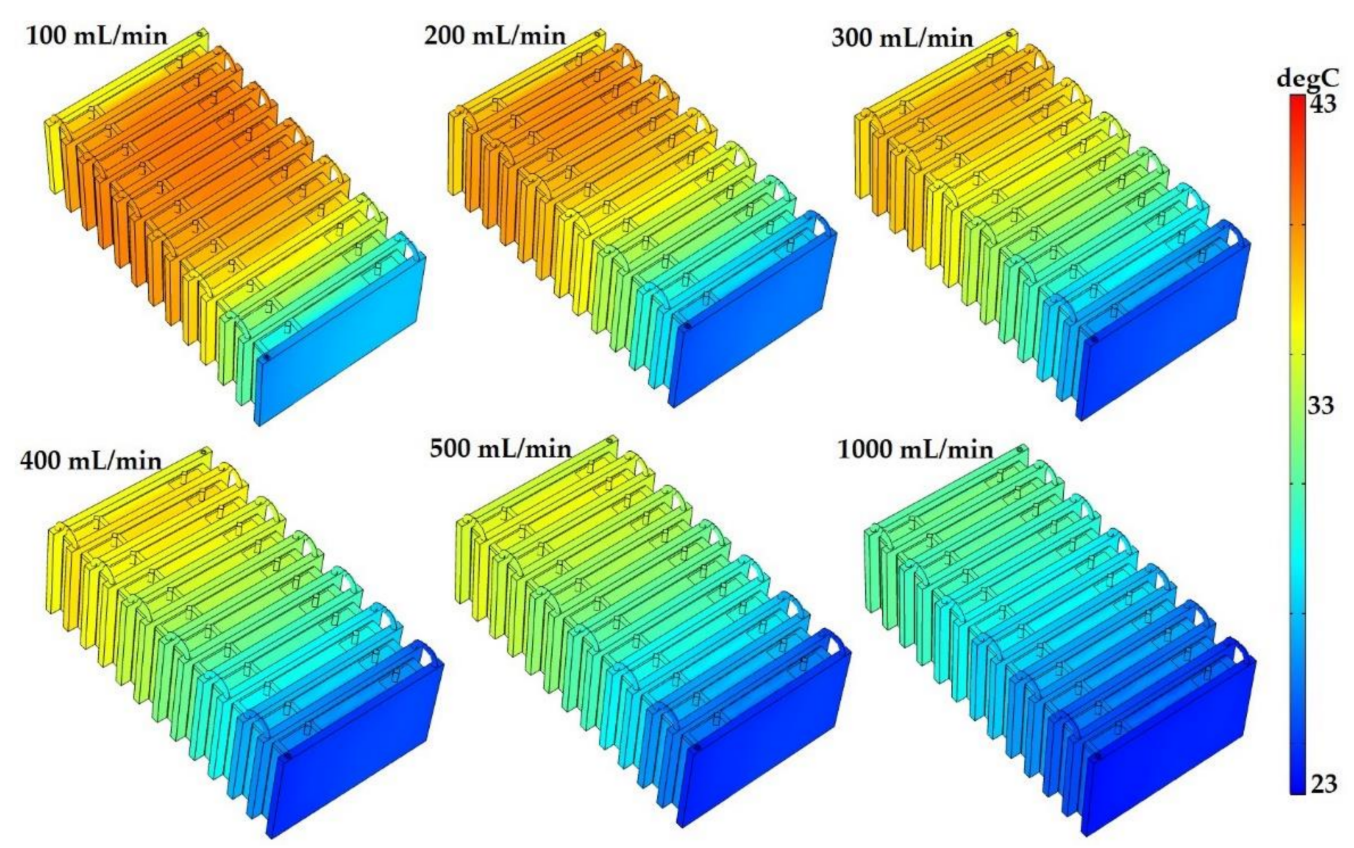

Figure 14. The temperature distribution of the module with different inlet flow rates.

Table 5 shows $\mathrm{T}_{\max }$ and $\Delta \mathrm{T}_{\max }$ for the proposed inlet flow rates. Based on the table, increasing the coolant's inlet flow rate reduces the maximum module's temperature and $\Delta \mathrm{T}_{\max }$ along with the cells. This reduction trend diminishes more when the inlet flow rate exceeds $500 \mathrm{~mL} / \mathrm{min}$. Nevertheless, increasing the inlet flow rate would increase the parasitic power consumption exponentially, which will lead to gradually weakening the advantages of increasing the inlet flow rate and increasing the corresponding costs [48].

Table 5. The thermal performance of the system with various inlet flow rates.

\begin{tabular}{ccc}
\hline Inlet Flow Rate & $\mathbf{T}_{\max }\left({ }^{\circ} \mathbf{C}\right)$ & $\Delta \mathbf{T}_{\max }\left({ }^{\circ} \mathbf{C}\right)$ \\
\hline $100 \mathrm{~mL} / \mathrm{min}$ (Main case) & 40.3 & 9.1 \\
$200 \mathrm{~mL} / \mathrm{min}$ & 39.7 & 7.6 \\
$300 \mathrm{~mL} / \mathrm{min}$ & 38.7 & 7.9 \\
$400 \mathrm{~mL} / \mathrm{min}$ & 37.5 & 7.4 \\
$500 \mathrm{~mL} / \mathrm{min}$ & 36.4 & 6.8 \\
$1000 \mathrm{~mL} / \mathrm{min}$ & 33.2 & 5.1 \\
\hline
\end{tabular}

\subsection{Impact of the Inlet Temperature}

The inlet temperature of the coolant is one of the crucial structural parameters to uniformize the temperature alongside the cells in the module, which is evaluated in 
this section, as shown in Figure 15. The coolant inlet temperature affects the cooling performance parameters such as $\Delta \mathrm{T}_{\max }$ between the coldest and hottest points of the module monitored by the thermocouples. As can be seen, when increasing the inlet temperature of the coolant, the heat transfer of the cells is faster and closer to the coolant's temperature, leading to gradually decreasing $\Delta \mathrm{T}_{\max }$. However, $\mathrm{T}_{\max }$ remains almost constant-both inlet temperatures of $30^{\circ} \mathrm{C}$ and $40^{\circ} \mathrm{C}$ exhibit good thermal performance under high current rates.
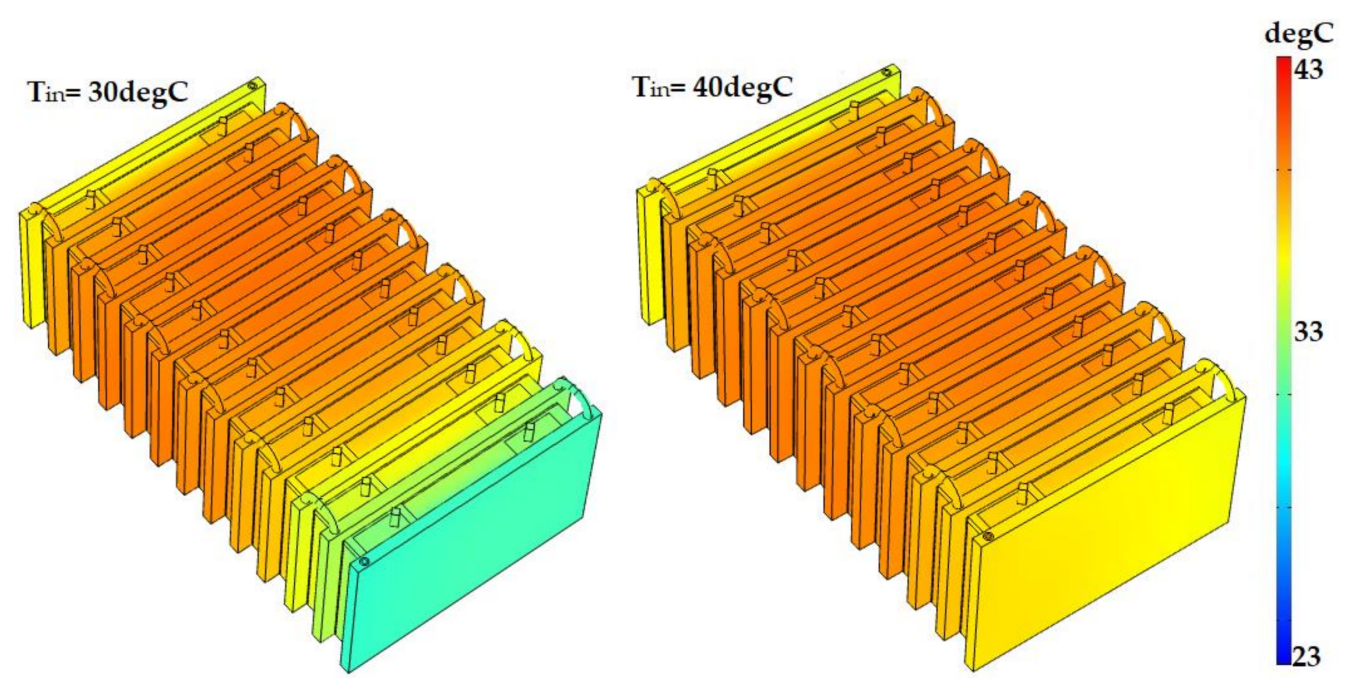

Figure 15. The temperature distribution of the module with different inlet temperatures.

$\mathrm{T}_{\max }$ and $\Delta \mathrm{T}_{\max }$ are evaluated in detail in Table 6. According to the data in Table 6, $\mathrm{T}_{\max }$ and $\Delta \mathrm{T}_{\max }$ with an inlet temperature of $30^{\circ} \mathrm{C}$ are $40.4{ }^{\circ} \mathrm{C}$ and $3.9^{\circ} \mathrm{C}$, respectively, in which $\Delta \mathrm{T}_{\max }$ is reduced by $57 \%$ compared with the main case study, where the inlet temperature of the coolant is $23{ }^{\circ} \mathrm{C}$. In addition, for the inlet temperature of $40{ }^{\circ} \mathrm{C}, \Delta \mathrm{T}_{\max }$ is diminished by $84 \%$ compared to the main case study, showing the importance of this factor in the design of the LCTMS.

Table 6. The thermal performance of the system with various inlet temperatures.

\begin{tabular}{ccc}
\hline Inlet Temperature $\left({ }^{\circ} \mathrm{C}\right)$ & $\mathrm{T}_{\max }\left({ }^{\circ} \mathrm{C}\right)$ & $\Delta \mathbf{T}_{\max }\left({ }^{\circ} \mathrm{C}\right)$ \\
\hline $23\left({ }^{\circ} \mathrm{C}\right)$ (Main case) & 40.3 & 9.1 \\
$30\left({ }^{\circ} \mathrm{C}\right)$ & 40.4 & 3.9 \\
$40\left({ }^{\circ} \mathrm{C}\right)$ & 40.4 & 1.4 \\
\hline
\end{tabular}

\subsection{Optimization of the Inlet and Outlet Positions}

In the LiC module with the LCTMS as a cooling solution, the heat from the LiCs is transferred to the liquid medium through the copper pipes to the aluminum cold plates. The inlet and outlet positions have a significant impact on the performance of the proposed TMS. Therefore, the thermal performance of the LiC module with LCTMS is evaluated in detail at different inlet and outlet positions when the inlet flow rate, inlet temperature, and the other initial and boundary conditions are kept constant. In this regard, four different topologies are proposed based on Figure 16. P1 has two inlets in the first and the last cold plates, where its two outlets are placed in the middle of the module. P2 has two inlets in the first cold plate, and the middle of the module, where one of the outlets is in the middle and the other one is placed in the last cold plate. P3 has three inlets and three outlets, and P4 has four inlets and four outlets. 


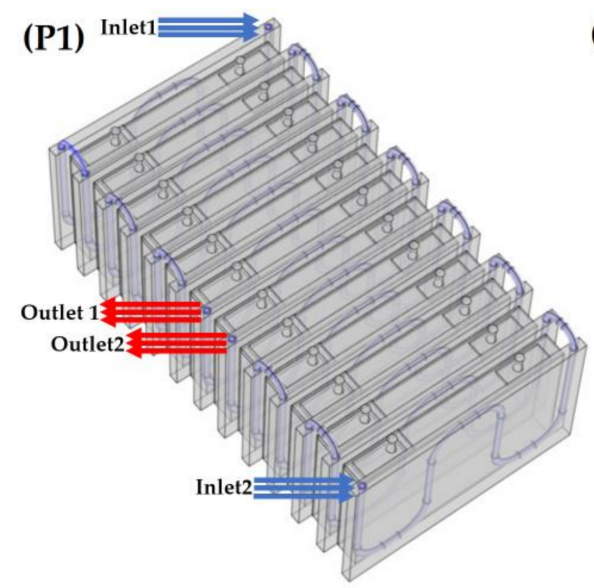

(P2)

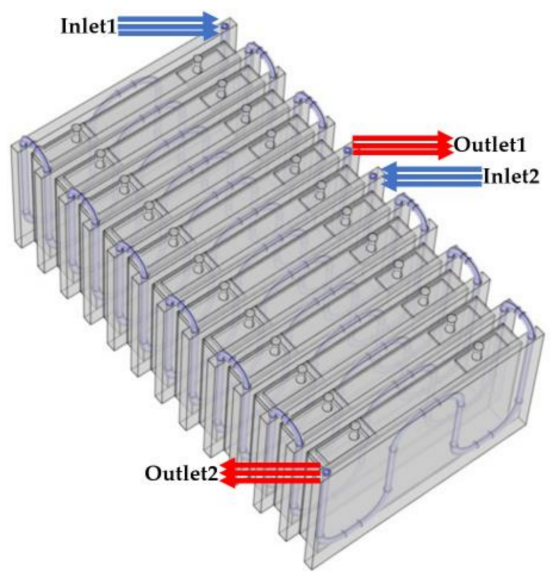

(P3)

(P4)
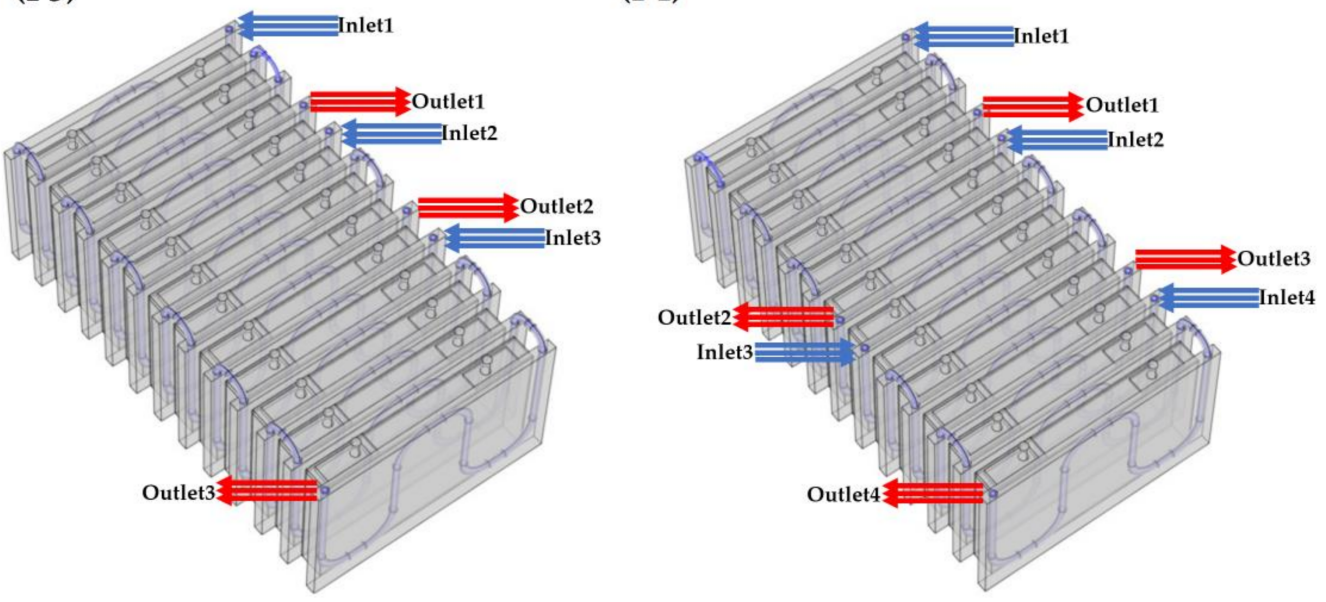

Figure 16. The proposed schematic of different inlet and outlet positions.

As the temperature distribution of the module for four various inlet and outlet positions is exhibited in Figure 17 and is listed in Table 7, P1 does not show good performance regarding $\mathrm{T}_{\max }$ and $\Delta \mathrm{T}_{\max }$. Compared to the main case study, the P2 case study shows better performance than P1 while decreasing $\mathrm{T}_{\max }$ by $1.7 \%$ and $\Delta \mathrm{T}_{\max }$ by $25.2 \%$. The P3 and $\mathrm{P} 4$ case studies behave almost the same, showing that increasing the number of inlets and outlets may result in a better outcome, but a greater increase will not guarantee a greater reduction in terms of $\Delta \mathrm{T}_{\max }$ or $\mathrm{T}_{\max }$. $\mathrm{P} 3$ can be the best choice in this section due to better results and optimum inlet and outlet points. This case study decreases $\mathrm{T}_{\max }$ by $3.5 \%$ and $\Delta \mathrm{T}_{\max }$ by $63.7 \%$, respectively.

\subsection{The Impact of the Number of Arcs in the Coolant Path}

The number of arcs in the tube is of high importance for thermal performance analysis. In this context, the number of arcs is increased from two arcs (the main case study) to three arcs in the LCTMS (Figure 18). As is shown in Figure 19 and Table 8, by increasing the number of arcs in the coolant path design, $\mathrm{T}_{\max }$ is decreased by $7.5 \%$. In comparison, $\Delta \mathrm{T}_{\max }$ is decreased by $63.7 \%$, compared to the main case study. 

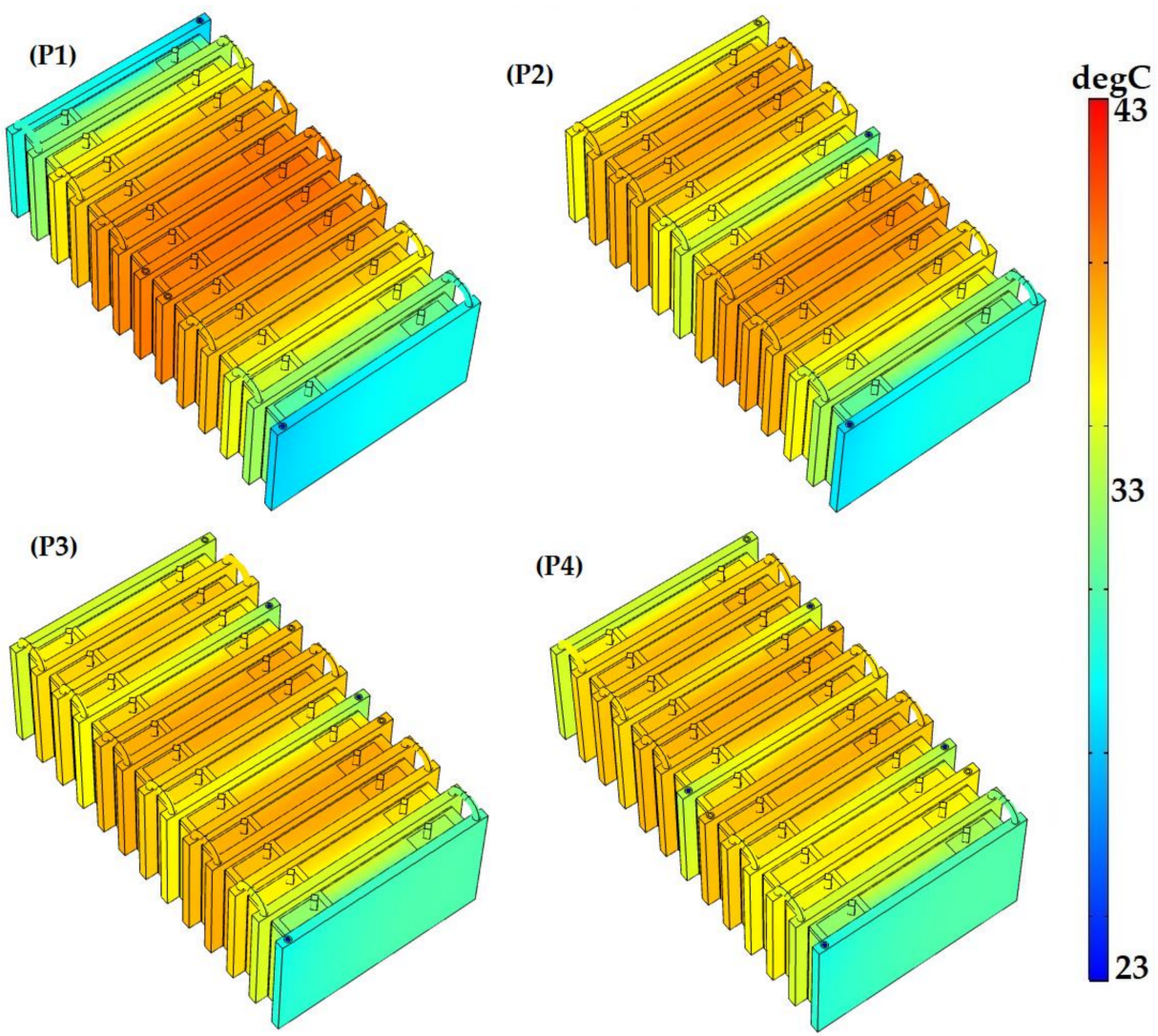

Figure 17. The temperature distribution of the module with different inlet and outlet positions.

Table 7. The thermal performance of the system with different inlet and outlet positions.

\begin{tabular}{ccc}
\hline Inlet Temperature $\left({ }^{\circ} \mathbf{C}\right)$ & $\mathbf{T}_{\max }\left({ }^{\circ} \mathbf{C}\right)$ & $\Delta \mathbf{T}_{\max }\left({ }^{\circ} \mathbf{C}\right)$ \\
\hline Main case study & 40.3 & 9.1 \\
P1 & 40.3 & 10.1 \\
P2 & 39.6 & 6.8 \\
P3 & 38.9 & 3.3 \\
P4 & 38.8 & 3.1 \\
\hline
\end{tabular}

two arcs per tube

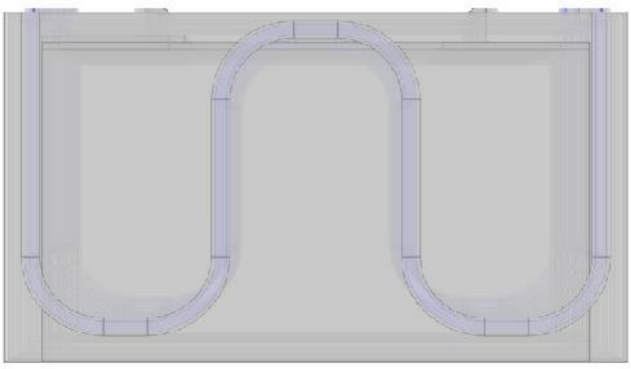

Figure 18. Various arc numbers per tube in the path of the cold plate. three arcs per tube

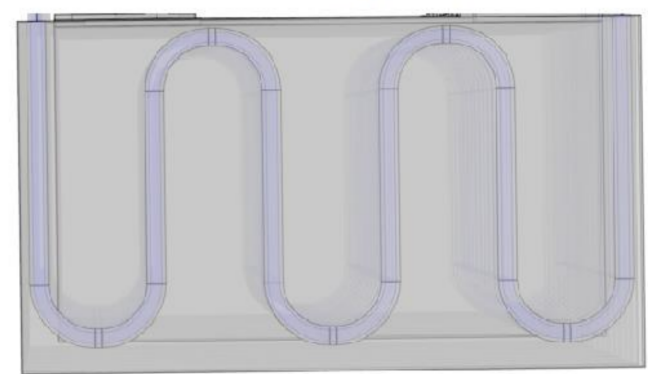



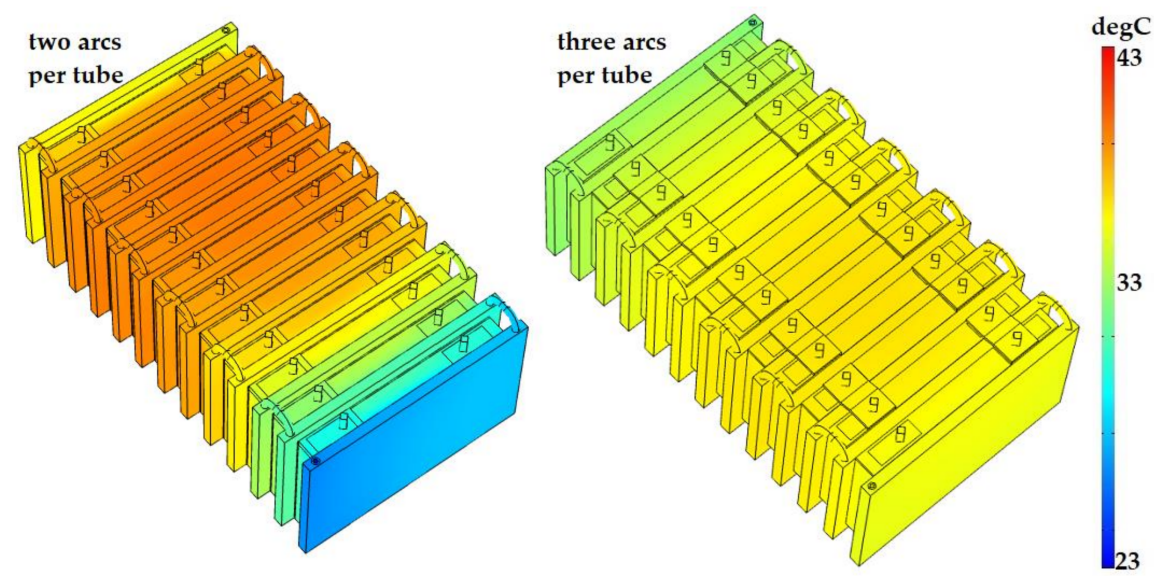

Figure 19. The temperature distribution of the module when using two different tube structures.

Table 8. The thermal performance of the system with different arc numbers.

\begin{tabular}{ccc}
\hline Inlet Temperature $\left({ }^{\circ} \mathrm{C}\right)$ & $\mathbf{T}_{\max }\left({ }^{\circ} \mathbf{C}\right)$ & $\Delta \mathbf{T}_{\max }\left({ }^{\circ} \mathbf{C}\right)$ \\
\hline Two arcs (main case) & 40.3 & 9.1 \\
Three arcs & 37.3 & 2.9 \\
\hline
\end{tabular}

\subsection{The Selected Optimal Solutions}

In this section, two optimal solutions are proposed to evaluate the performance of the developed 1D/3D thermal model with the optimized boundaries. The best scenarios of the numerical simulations have been selected to set in the LCTMS cooling system to conclude with the most optimal solution regarding the proposed geometry and structure. In this context, the inlet flow rate of $500 \mathrm{~mL} / \mathrm{min}$, with an inlet temperature of $30^{\circ} \mathrm{C}$, was set in the model. In addition, the P3 inlet and outlet position where three inlets and three outlets have been designed in the system was selected as the inlet and outlet topology. With the defined conditions mentioned above, two arcs per tube were selected for the first optimized solution, while the second optimized solution uses three arcs per tube.

By mixing such optimal cases for two arcs in the first optimized solution, $\mathrm{T}_{\max }$ and $\Delta \mathrm{T}_{\max }$ are $37.1^{\circ} \mathrm{C}$ and $1.4{ }^{\circ} \mathrm{C}$, respectively. This trend shows $8 \%$ and $85 \%$ improvement compared with the main case study in $\mathrm{T}_{\max }$ and $\Delta \mathrm{T}_{\max }$, respectively. The temperature distribution of this optimal solution is depicted in Figure 20.

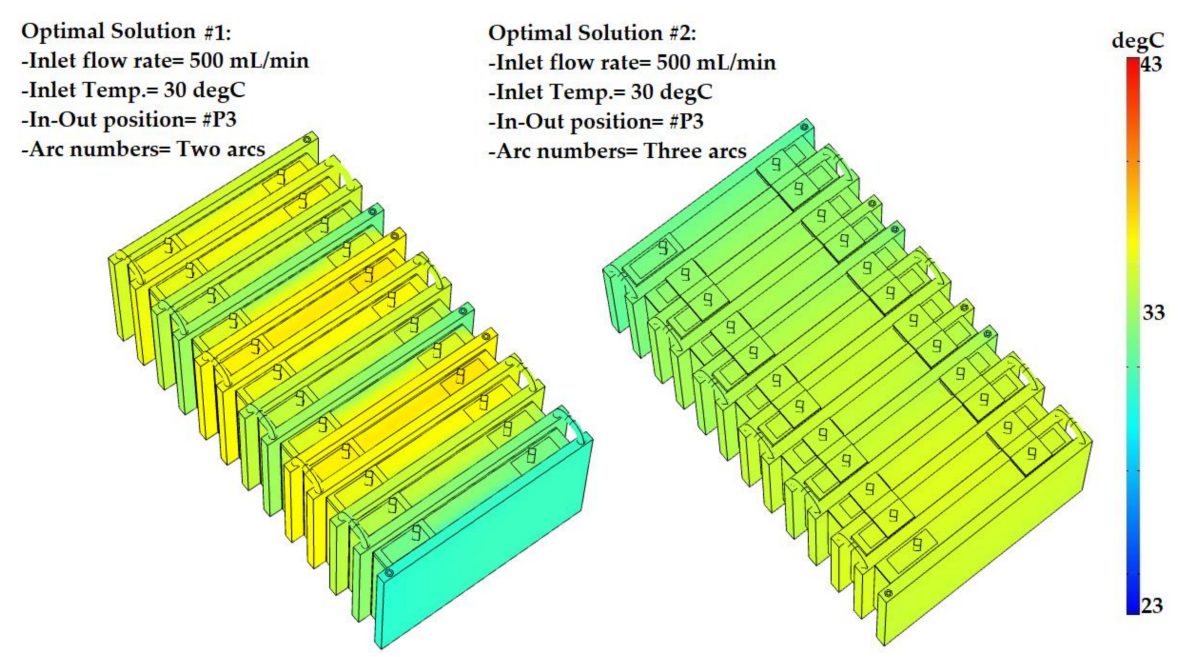

Figure 20. The temperature distribution of the module when using the LCTMS with the optimal solutions as the main parameters. 
The second optimized case using three arcs per channel in the cooling path can control $\mathrm{T}_{\max }$ at $35.7{ }^{\circ} \mathrm{C}$, showing an $11.5 \%$ improvement compared to the main case study. In addition, this case study reduced the temperature uniformity by $79.1 \%$. Overall, the optimal solution \#2 would be better due to the lower $\mathrm{T}_{\max }$ and temperature uniformity below $2{ }^{\circ} \mathrm{C}$. The comparative study based on the explained results is shown in Table 9.

Table 9. The thermal performance of the system for the optimal solutions.

\begin{tabular}{ccc}
\hline Inlet Temperature $\left({ }^{\circ} \mathbf{C}\right)$ & $\mathbf{T}_{\max }\left({ }^{\circ} \mathbf{C}\right)$ & $\Delta \mathbf{T}_{\max }\left({ }^{\circ} \mathbf{C}\right)$ \\
\hline Two arcs (Main case) & 40.3 & 9.1 \\
Optimal case \#1 & 37.1 & 1.4 \\
Optimal case \#2 & 35.7 & 1.9 \\
\hline
\end{tabular}

\section{Conclusions}

In the present article, a module of $12 \mathrm{LiCs}$ was used to evaluate a liquid-cooled thermal management system (LCTMS). Prior to testing the module, predicting the electrical parameters is of high importance since the extracted electrical and thermal parameters can lead to predicting the heat loss with high precision. Therefore, a 1D electro-thermal model was developed from $-30{ }^{\circ} \mathrm{C}$ to $+60^{\circ} \mathrm{C}$. Moreover, high current rates were applied, including $0.1 \mathrm{~A}$ to $500 \mathrm{~A}$ as a loading profile. The open-circuit voltage, the resistances and capacitance of the cell, and thermal parameters were extracted in this regard. The voltage error was $\pm 5 \%$ and $\pm 3 \%$ for current rates higher than $100 \mathrm{~A}$ and lower than $100 \mathrm{~A}$, respectively. Then, the $3 \mathrm{D}$ thermal model evaluation was performed experimentally and optimized numerically, thanks to the extracted parameters from the electro-thermal model. The effects of the inlet coolant flow rate, inlet coolant temperature, inlet and outlet positions, and the number of arcs were examined. The cycling profile consisted of a $1400 \mathrm{~s}$ continuous 150 A current rate without a rest period. The conclusions can be drawn as follows:

1. In the case of cycling the module under the $150 \mathrm{~A}$ current profile, the maximum temperature $\left(\mathrm{T}_{\max }\right)$ of the module exceeds $70^{\circ} \mathrm{C}$, which may lead to thermal runaway.

2. The LCTMS with a $100 \mathrm{~mL} / \mathrm{min}$ inlet flow rate, $23^{\circ} \mathrm{C}$ inlet temperature, and two arcs in the coolant channel (main case study) can control $\mathrm{T}_{\max }$ at $40.3{ }^{\circ} \mathrm{C}$, which shows $42.4 \%$ improvement compared to the natural convection. $\Delta \mathrm{T}_{\max }$ was $9.1^{\circ} \mathrm{C}$, which can be improved.

3. The 1D electro-thermal model extracted the electrical and thermal parameters with high precision, used in the 3D thermal model. The 3D thermal model was validated against the experiments with an error lower than $2 \%$, employed for optimization purposes. The optimization parameters were the inlet coolant flow rate, inlet coolant temperature, inlet and outlet positions, and the number of arcs per coolant channel.

4. Increasing the inlet flow rate of the coolant from $100 \mathrm{~mL} / \mathrm{min}$ to $500 \mathrm{~mL} / \mathrm{min}$ decreased $\mathrm{T}_{\max }$ and $\Delta \mathrm{T}_{\max }$ by $9.7 \%$ and $25.2 \%$, respectively. By increasing the inlet flow rate to $1000 \mathrm{~mL} / \mathrm{min}$, these values were $17.6 \%$ and $43.9 \%$, showing the importance of the inlet flow rate to minimize $\mathrm{T}_{\max }$ and $\Delta \mathrm{T}_{\max }$.

5. Increasing the inlet temperature did not significantly impact $\mathrm{T}_{\max }$ but was enhanced $\Delta \mathrm{T}_{\max }$. By increasing the inlet temperature from $23^{\circ} \mathrm{C}$ to $30^{\circ} \mathrm{C}$ and $40{ }^{\circ} \mathrm{C}, \Delta \mathrm{T}_{\max }$ was reduced by $57 \%$ and $84 \%$, respectively.

6. Inlet and outlet configuration had a significant effect on $\mathrm{T}_{\max }$ and $\Delta \mathrm{T}_{\max }$. The best scenario for the LCTMS would be three inlets and three outlets, where $\mathrm{T}_{\max }$ and $\Delta \mathrm{T}_{\max }$ were decreased by $3.5 \%$ and $63.7 \%$, respectively.

7. Compared to the main case study, increasing the number of arcs in the coolant path design reduced $\mathrm{T}_{\max }$ by $7.5 \%$ and $\Delta \mathrm{T}_{\max }$ by $63.7 \%$.

8. The most optimal scenario for the LCTMS would be the inlet coolant flow rate of $500 \mathrm{~mL} / \mathrm{min}$, the inlet temperature of $30^{\circ} \mathrm{C}$, three inlets and three outlets, and three arcs in the coolant path. This scenario decreased $\mathrm{T}_{\max }$ and $\Delta \mathrm{T}_{\max }$ by $11.5 \%$ and $79.1 \%$, respectively. 
Author Contributions: Conceptualization, methodology, software, validation, formal analysis, investigation, writing_-original journal draft by D.K.; writing—review and editing by H.B., M.A. and S.K.; supervision, writing-review and editing by J.V.M. and M.B. All authors have read and agreed to the published version of the manuscript.

Funding: This research received no external funding.

Institutional Review Board Statement: Not applicable.

Informed Consent Statement: Not applicable.

Data Availability Statement: Not applicable.

Acknowledgments: This research is based on work supported by JSR Micro NV and Flanders Make.

Conflicts of Interest: The authors declare no conflict of interest.

\section{References}

1. Gandoman, F.H.; Jaguemont, J.; Goutam, S.; Gopalakrishnan, R.; Firouz, Y.; Kalogiannis, T.; Omar, N.; van Mierlo, J. Concept of reliability and safety assessment of lithium-ion batteries in electric vehicles: Basics, progress, and challenges. Appl. Energy 2019, 251, 113343. [CrossRef]

2. Soltani, M.; Jaguemont, J.; Boninsegna, M.; Berckmans, G.; Abdel-monem, M. Thermal management system for a Lithium-ion Capacitor Module with air cooling strategy. In Proceedings of the International Electric Vehicle Symposium and Exhibition (EVS), Stuttgart, Germany, 9-11 October 2017; pp. 1-10.

3. Soltani, M.; Ronsmans, J.; Jaguemont, J.; van Mierlo, J.; van den Bossche, P.; Omar, N. A Three-dimensional thermal model for a commercial lithium-ion capacitor battery pack with non-uniform temperature distribution. In Proceedings of the 2019 IEEE International Conference on Industrial Technology (ICIT), Melbourne, Australia, 13-15 February 2019; pp. 1126-1131. [CrossRef]

4. Khaleghi, S.; Karimi, D.; Beheshti, S.H.; Hosen, S.; Behi, H.; Berecibar, M.; van Mierlo, J. Online health diagnosis of lithium-ion batteries based on nonlinear autoregressive neural network. Appl. Energy 2021, 282, 116159. [CrossRef]

5. Soltani, M.; de Sutter, L.; Ronsmans, J.; van Mierlo, J. A high current electro-thermal model for lithium-ion capacitor technology in a wide temperature range. J. Energy Storage 2020, 31, 101624. [CrossRef]

6. Soltani, M.; Ronsmans, J.; Kakihara, S.; Jaguemont, J.; van den Bossche, P.; van Mierlo, J.; Omar, N. Hybrid battery/lithium-ion capacitor energy storage system for a pure electric bus for an urban transportation application. Appl. Sci. 2018, 8, 1176. [CrossRef]

7. Karimi, D.; Khaleghi, S.; Behi, H.; Beheshti, H.; Hosen, M.S.; Akbarzadeh, M.; van Mierlo, J.; Berecibar, M. Lithium-ion capacitor lifetime extension through an optimal thermal management system for smart grid applications. Energies 2021, 14, 2907. [CrossRef]

8. Behi, H.; Karimi, D.; Jaguemont, J.; Gandoman, F.H.; Kalogiannis, T.; Berecibar, M.; van Mierlo, J. Novel thermal management methods to improve the performance of the Li-ion batteries in high discharge current applications. Energy 2021, $224,120165$. [CrossRef]

9. Hosen, M.S.; Karimi, D.; Kalogiannis, T.; Pirooz, A.; Jaguemont, J.; Berecibar, M.; van Mierlo, J. Electro-aging model development of nickel-manganese-cobalt lithium-ion technology validated with light and heavy-duty real-life profiles. J. Energy Storage 2020, 28, 101265. [CrossRef]

10. Karimi, D.; Behi, H.; Akbarzadeh, M.; van Mierlo, J.; Berecibar, M. Holistic 1D Electro-Thermal Model Coupled to 3D Thermal Model for Hybrid Passive Cooling System Analysis in Electric Vehicles. Energies 2021, 14, 5924. [CrossRef]

11. Karimi, D.; Behi, H.; Jaguemont, J.; el Baghdadi, M.; van Mierlo, J.; Hegazy, O. Thermal Concept Design of MOSFET Power Modules in Inverter Subsystems for Electric Vehicles. In Proceedings of the 2019 9th International Conference on Power and Energy Systems (ICPES), Perth, Australia, 10-12 December 2019; pp. 1-6. [CrossRef]

12. Zhang, C.; Allafi, W.; Dinh, Q.; Ascencio, P.; Marco, J. Online estimation of battery equivalent circuit model parameters and state of charge using decoupled least squares technique. Energy 2018, 142, 678-688. [CrossRef]

13. Samba, A.; Omar, N.; Gualous, H.; Firouz, Y.; van den Bossche, P.; van Mierlo, J.; Boubekeur, T.I. Development of an Advanced Two-Dimensional Thermal Model for Large size Lithium-ion Pouch Cells. Electrochim. Acta 2014, 117, 246-254. [CrossRef]

14. Firouz, Y.; Omar, N.; van den Bossche, P.; van Mierlo, J. Electro-thermal modeling of new prismatic lithium-ion capacitors. IEEE Veh. Power Propuls. Conf. 2014, 2, 1-6. [CrossRef]

15. Behi, H.; Karimi, D.; Youssef, R.; Patil, M.S.; van Mierlo, J.; Berecibar, M. Comprehensive Passive Thermal Management Systems for Electric Vehicles. Energies 2021, 14, 3881. [CrossRef]

16. Karimi, D.; Behi, H.; Jaguemont, J.; Berecibar, M.; van Mierlo, J. A refrigerant-based thermal management system for a fast charging process for lithium-ion batteries. In Proceedings of the International Conference on Renewable Energy Systems and Environmental Engineering (IRESE), Brussels, Belgium, 18 December 2020; pp. 1-6.

17. Behi, H.; Karimi, D.; Jaguemont, J.; Gandoman, F.H.; Khaleghi, S.; van Mierlo, J.; Berecibar, M. Aluminum heat sink assisted air-cooling thermal management system for high current applications in electric vehicles. In Proceedings of the 2020 AEIT International Conference of Electrical and Electronic Technologies for Automotive (AEIT AUTOMOTIVE), Turin, Italy, 18-20 November 2020; pp. 1-6. 
18. Behi, H.; Behi, M.; Karimi, D.; Jaguemont, J.; Ghanbarpour, M.; Behnia, M.; Berecibar, M.; van Mierlo, J. Heat pipe air-cooled thermal management system for lithium-ion batteries: High power applications. Appl. Therm. Eng. 2020, 183, 116240. [CrossRef]

19. Behi, H.; Karimi, D.; Gandoman, F.H.; Akbarzadeh, M.; Khaleghi, S.; Kalogiannis, T.; Hosen, M.S.; Jaguemont, J.; van Mierlo, J.; Berecibar, M. PCM assisted heat pipe cooling system for the thermal management of an LTO cell for high-current profiles. Case Stud. Therm. Eng. 2021, 25, 100920. [CrossRef]

20. Karimi, D.; Behi, H.; Jaguemont, J.; Berecibar, M.; van Mierlo, J. Investigation of extruded heat sink assisted air cooling system for lithium-ion capacitor batteries. In Proceedings of the International Conference on Renewable Energy Systems and Environmental Engineering (IRESE), Brussels, Belgium, 18 December 2020; pp. 1-6.

21. Behi, H.; Behi, M.; Ghanbarpour, A.; Karimi, D.; Azad, A.; Ghanbarpour, M.; Behnia, M. Enhancement of the Thermal Energy Storage Using Heat-Pipe-Assisted Phase Change Material. Energies 2021, 14, 6176. [CrossRef]

22. Behi, H.; Karimi, D.; Behi, M.; Jaguemont, J.; Ghanbarpour, M.; Behnia, M.; Berecibar, M.; van Mierlo, J. Thermal management analysis using heat pipe in the high current discharging of lithium-ion battery in electric vehicles. J. Energy Storage 2020, $32,101893$. [CrossRef]

23. Behi, H.; Karimi, D.; Jaguemont, J.; Berecibar, M.; van Mierlo, J. Experimental study on cooling performance of flat heat pipe for lithium-ion battery at various inclination angels. Energy Perspect. 2020, 1, 77-92.

24. Karimi, D.; Jaguemont, J.; Behi, H.; Berecibar, M.; van den Bossche, P.; van Mierlo, J. Passive cooling based battery thermal management using phase change materials for electric vehicles. In EVS33 International Electric Vehicle Symposium; The Electric Drive Transportation Association (EDTA): Washington, DC, USA, 2020; pp. 1-12.

25. Jaguemont, J.; Karimi, D.; van Mierlo, J. Investigation of a Passive Thermal Management System for Lithium-Ion Capacitors. IEEE Trans. Veh. Technol. 2019, 68, 10518-10524. [CrossRef]

26. Karimi, D.; Hosen, M.S.; Behi, H.; Khaleghi, S.; Akbarzadeh, M.; van Mierlo, J.; Berecibar, M. A hybrid thermal management system for high power lithium-ion capacitors combining heat pipe with phase change materials. Heliyon 2021, 7, e07773. [CrossRef]

27. Murali, G.; Sravya, G.S.N.; Jaya, J.; Vamsi, V.N. A review on hybrid thermal management of battery packs and it's cooling performance by enhanced PCM. Renew. Sustain. Energy Rev. 2021, 150, 111513. [CrossRef]

28. Kumar, P.; Chaudhary, D.; Varshney, P.; Varshney, U.; Yahya, S.M.; Rafat, Y. Critical review on battery thermal management and role of nanomaterial in heat transfer enhancement for electrical vehicle application. J. Energy Storage 2020, 32, 102003. [CrossRef]

29. Behi, M.; Shakorian-poor, M.; Mirmohammadi, S.A.; Behi, H.; Rubio, J.I.; Nikkam, N.; Farzaneh-Gord, M.; Gan, Y.; Behnia, M. Experimental and numerical investigation on hydrothermal performance of nanofluids in micro-tubes. Energy 2020, 193, 116658. [CrossRef]

30. Pu, L.; Zhang, S.; Xu, L.; Ma, Z.; Wang, X. Numerical study on the performance of shell-and-tube thermal energy storage using multiple PCMs and gradient copper foam, Renew. Energy 2021, 174, 573-589. [CrossRef]

31. Karimi, D.; Behi, H.; Jaguemont, J.; Sokkeh, M.A.; Kalogiannis, T.; Hosen, M.S.; Berecibar, M.; van Mierlo, J. Thermal performance enhancement of phase change material using aluminum-mesh grid foil for lithium-capacitor modules. J. Energy Storage 2020, 30, 101508. [CrossRef]

32. Möller, S.; Karimi, D.; Vanegas, O.; el Baghdadi, M.; Kospach, A.; Lis, A.; Hegazy, O.; Abart, C.; Offenbach, Â.B.Â. Application considerations for Double Sided Cooled Modules in Automotive Environment. 2020. Available online: https://ieeexplore.ieee. org/document/9097721 (accessed on 16 November 2020).

33. Behi, H.; Karimi, D.; Behi, M.; Ghanbarpour, M.; Jaguemont, J.; Sokkeh, M.A.; Gandoman, F.H.; Berecibar, M.; van Mierlo, J. A new concept of thermal management system in Li-ion battery using air cooling and heat pipe for electric vehicles. Appl. Therm. Eng. 2020, 174, 115280. [CrossRef]

34. Karimi, D.; Behi, H.; Jaguemont, J.; Berecibar, M.; van Mierlo, J. Optimized air-cooling thermal management system for high power lithium-ion capacitors. Energy Perspect. 2020, 1, 93-105.

35. Akbarzadeh, M.; Kalogiannis, T.; Jaguemont, J.; Jin, L.; Behi, H.; Karimi, D.; Beheshti, H.; van Mierlo, J.; Berecibar, M. A comparative study between air cooling and liquid cooling thermal management systems for a high-energy lithium-ion battery module. Appl. Therm. Eng. 2021, 198, 117503. [CrossRef]

36. Gungor, S.; Cetkin, E.; Lorente, S. Canopy-to-canopy liquid cooling for the thermal management of lithium-ion batteries, a constructal approach. Int. J. Heat Mass Transf. 2022, 182, 121918. [CrossRef]

37. Tang, Z.; Liu, Z.; Li, J.; Cheng, J. A lightweight liquid cooling thermal management structure for prismatic batteries. J. Energy Storage 2021, 42, 103078. [CrossRef]

38. Tang, X.; Guo, Q.; Li, M.; Wei, C.; Pan, Z.; Wang, Y. Performance analysis on liquid-cooled battery thermal management for electric vehicles based on machine learning. J. Power Sources 2021, 494, 229727. [CrossRef]

39. Cao, J.; Wu, Y.; Ling, Z.; Fang, X.; Zhang, Z. Upgrade strategy of commercial liquid-cooled battery thermal management system using electric insulating flexible composite phase change materials. Appl. Therm. Eng. 2021, 199, 117562. [CrossRef]

40. Rui, X.; Feng, X.; Wang, H.; Yang, H.; Zhang, Y.; Wan, M.; Wei, Y.; Ouyang, M. Synergistic effect of insulation and liquid cooling on mitigating the thermal runaway propagation in lithium-ion battery module. Appl. Therm. Eng. 2021, 199, 117521. [CrossRef]

41. Karimi, D.; Behi, H.; Hosen, M.S.; Jaguemont, J.; Berecibar, M.; van Mierlo, J. A compact and optimized liquid-cooled thermal management system for high power lithium-ion capacitors. Appl. Therm. Eng. 2021, 185, 116449. [CrossRef] 
42. Fan, L.; Khodadadi, J.M.; Pesaran, A.A. A parametric study on thermal management of an air-cooled lithium-ion battery module for plug-in hybrid electric vehicles. J. Power Sources 2013, 238, 301-312. [CrossRef]

43. Bernardi, D. A General Energy Balance for Battery Systems. J. Electrochem. Soc. 1985, 132, 5. [CrossRef]

44. Zhang, J.; Huang, J.; Li, Z.; Wu, B.; Nie, Z.; Sun, Y.; An, F.; Wu, N. Comparison and validation of methods for estimating heat generation rate of large-format lithium-ion batteries. J. Therm. Anal. Calorim. 2014, 117, 447-461. [CrossRef]

45. Panchal, S.; Dincer, I.; Agelin-Chaab, M.; Fraser, R.; Fowler, M. Experimental and theoretical investigations of heat generation rates for a water cooled LiFePO4 battery. Int. J. Heat Mass Transf. 2016, 101, 1093-1102. [CrossRef]

46. Gnielinski, V. New equations for heat and mass transfer in turbulent pipe and channel flow. Int. Chem. Eng. 1976, 16, 359-368.

47. Karwa, R.; Solanki, S.C.; Saini, J.S. Heat transfer coefficient and friction factor correlations for the transitional flow regime in rib-roughened rectangular ducts. Int. J. Heat Mass Transf. 1999, 42, 1597-1615. [CrossRef]

48. Tan, X.; Lyu, P.; Fan, Y.; Rao, J.; Ouyang, K. Numerical investigation of the direct liquid cooling of a fast-charging lithium-ion battery pack in hydrofluoroether. Appl. Therm. Eng. 2021, 196, 117279. [CrossRef] 